Universidade de São Paulo

Faculdade de Zootecnia e Engenharia de Alimentos

\title{
Licopeno no bem-estar de juvenis de tilápia do Nilo (Oreochromis niloticus): Efeito sobre desempenho e parâmetros bioquímicos
}




\section{Licopeno no bem-estar de juvenis de tilápia do Nilo (Oreochromis niloticus): Efeito sobre desempenho e parâmetros bioquímicos}

Tese apresentada à Faculdade de Zootecnia e Engenharia de Alimentos da Universidade de São Paulo, como parte dos requisitos para a obtenção do Título de Doutor em Zootecnia.

Área de Concentração: Qualidade e Produtividade Animal

Orientadora: Profa. Dra. Mariza Pires de Melo Co-orientadora: Profa. Dra. Elyara Maria Pereira-da- Silva

\section{Pirassununga}

2009 
Dados Internacionais de Catalogação na Publicação

Serviço de Biblioteca e Informação da Faculdade de Zootecnia e Engenharia de Alimentos da Universidade de São Paulo

M779L

Montes-Girao de Oliveira, Pamela Jenny

Licopeno no bem-estar de juvenis de tilápia

do Nilo (Oreochromis niloticus): efeito sobre desempenho

e parâmetros bioquímicos / Pamela Jenny Montes Girao

de Oliveira -- Pirassununga, 2009.

$103 \mathrm{f}$.

Tese (Doutorado) -- Faculdade de Zootecnia e

Engenharia de Alimentos - Universidade de São Paulo.

Departamento de Ciências Básicas

Área de Concentração: Qualidade e Produtividade Animal.

Orientadora: Profa.Dra. Mariza Pires de Melo.

1. Tilápia do Nilo 2. Oreochromis niloticus

3. Bem-estar animal 4. Licopeno 5. Extresse oxidativo

I. Título. 
Dedico aos que amo, longe ou perto, sempre no meu coração, em especial para uma pessoa que além de ser boa amiga, trouxe e traz muita felicidade na minha vida, assim, hoje um anjo que vê por nós......pra você Dri.......... 


\section{AGRADECIMENTOS}

À Deus, por tudo...

À minha orientadora, Profa. Dra. Mariza Pires de Melo, pela acolhida, paciência, empenho e dedicação; à minha co-orientadora Profa. Dra. Elyara Maria Pereira-daSilva, pela ajuda e acolhida e as duas por acreditar em mim além da amizade,

Aos meus pais e irmã, que continuaram acreditando e me apoiando neste novo desafio,

Ao Paulitico, meu namorado que acabou esposo no decorrer desta tese, obrigada pela compreensão e cumplicidade em todos os momentos, pela ajuda nas horas precisas e por torcer por mim e a sua e agora minha família, pelos bons momentos compartilhados,

A família da minha saudosa amiga, Adriana A. Cuel Barone, Dri, agora minhas novas famílias, que tive a sorte de conquistar aqui em Pirassununga, Cuel -Assis Barone, sendo na verdade uma só, composta de pessoas boas, alegres e sinceras, às que sempre espero ter por perto,

À Profa. Dra. Carmen Fávaro Trindade, pela amizade e doação do licopeno imprescindível nesta tese e ao Marcelo, técnico do laboratório de Produtos Funcionais, pela ajuda na confecção das rações,

À Profa. Dra. Elisabete Macedo Viegas, pelo empréstimo de equipamentos necessários para o desenvolvimento do trabalho experimental,

A Silvana Piccoli Pugine, pela valiosa amizade e pela grande ajuda nas análises bioquímicas. As meninas do laboratório de Química Biológica, Lú e Andréia, pelas boas risadas e cafés da tarde compartilhados,

Ao Ricardo F. Oliveira, pela amizade e auxilio no período experimental, a todos os estagiários do Laboratório de Comportamento de Peixes (LACOPE), pela valiosa ajuda durante o experimento, aos amigos Franco, Juliana e Mirele pelo apoio na coleta de amostras no final dete trabalho, além da amizade.

A Sandra A. de Oliveira, pela ajuda nas análises de cortisol no Laboratório de Fisiologia Animal. 


\section{RESUMO}

O objetivo do presente estudo foi avaliar a hipótese de que a inclusão de licopeno na ração comercial reduz os efeitos negativos do estresse e melhora o desempenho de juvenis da tilápia do Nilo, Oreochromis niloticus. Para tal, foi realizado, primeiramente, um estudo que avaliou o efeito da suplementação com licopeno (100, 200, 400 e 800 mg/kg de ração) sobre a atrato-palatabilidade da ração. Numa segunda etapa foi avaliado o efeito da suplementação diária de licopeno $(800 \mathrm{mg} / \mathrm{kg}$ de ração), durante 60 dias, na promoção do bem-estar de juvenis dessa espécie submetidos a estresse de contenção de 90 minutos. Foram avaliados parâmetros zootécnicos como ganho de peso, conversão alimentar, fator de condição e taxa de crescimento especifico, consumo e parâmetros fisiológicos e bioquímicos como o nível de cortisol plasmático, o conteúdo de peroxidação lipídica, avaliação da cor instrumental do filé e a atividade das enzimas antioxidantes catalase (CAT) e glutationa redutase $(\mathrm{GR})$ e atividade da lactato desidrogenase (LDH) no músculo branco (filé) e vermelho. Os resultados foram submetidos à ANOVA e em caso de efeito significativo entre tratamentos, as médias foram comparadas pelo teste de Tukey $(p<0,05)$. A inclusão de licopeno não alterou a atrato-palatabilidade da ração comercial em nenhuma das concentrações estudadas. A suplementação com licopeno (800 mg/kg de ração) não alterou nenhum dos parâmetros zootécnicos avaliados: ganho em peso, conversão alimentar, fator de condição e taxa de crescimento especifico. Da mesma forma, não alterou o nível de peroxidação lipídica avaliado pelas substâncias reativas ao ácido tiobarbitúrico (TBARS) e a cor instrumental do filé dos peixes. Houve redução (34\%) na atividade da catalase no músculo branco dos peixes suplementados com licopeno, comparado aos animais do grupo controle (sem suplementação). Entretanto, a atividade de catalase na 
musculatura vermelha não foi alterada mediante a suplementação com licopeno; bem como a atividade da GR e LDH no músculo branco e vermelho. Evidenciou que o estresse de contenção aumenta o nível de cortisol plasmático (53\%), o nível de peroxidação lipídica do file (28\%) e também a atividade de CAT, GR e LDH no músculo branco $(31 \%, 32 \%$ e $29 \%$, respectivamente) e músculo vermelho ( $48 \%$, $46 \%$ e $44 \%$, respectivamente) dos animais submetidos ao estresse. Porém, a inclusão de licopeno na dieta aboliu os efeitos negativos do estresse de contenção, evitando a elevação dos níveis de cortisol, conteúdo de TBARS do filé e atividade das enzimas CAT, GR e LDH no músculo branco e vermelho. Concluiu-se que o licopeno veiculado na ração comercial, na proporção de $800 \mathrm{mg} / \mathrm{kg}$ de ração, reduz os efeitos negativos do estresse e não altera o desempenho de juvenis de tilápia do Nilo.

Palavras-Chave: Oreochromis niloticus, bem-estar, licopeno, estresse, estresse oxidativo, desempenho. 


\begin{abstract}
The aim of this study was to evaluate the hypothesis that the inclusion of lycopene in the commercial diet reduces the negative effects of stress and improves performance of juvenile Nile tilapia, Oreochromis niloticus. To this end was accomplished, first, a study that evaluated the effect of supplementation with lycopene (100, 200, 400 and $800 \mathrm{mg} / \mathrm{kg}$ of diet) on the attraction and palatability of the diet. In a second step, the effect of daily supplementation of lycopene $(800 \mathrm{mg} / \mathrm{kg}$ of diet) for 60 days, to promote the welfare of juveniles subjected to restraint stress for 90 minutes.
\end{abstract} Zootechnical parameters were evaluated as weight gain, feed conversion, condition factor and specific growth rate, consumption and physiological and biochemical parameters as the plasma cortisol level, the content of lipid peroxidation, instrumental color of the fillet and the activity of antioxidant enzymes catalase (CAT) and glutathione reductase $(G R)$ and activity of lactate dehydrogenase (LDH) in white muscle (fillet) and red muscle. The results were submitted to ANOVA and in case of significant effect between treatments, means were compared by Tukey test $(p<0.05)$. The inclusion of lycopene did not affect the attraction and palatability of commercial feed in any of the concentrations studied. Supplementation with lycopene $(800 \mathrm{mg} / \mathrm{kg}$ diet) did not alter any of the zootechnical parameters evaluated: weight gain, feed conversion, condition factor and specific growth rate. Likewise, did not alter the level of lipid peroxidation evaluated by thiobarbituric acid reactive substance (TBARS) and instrumental color of the fillet of fish. There was a reduction (34\%) in catalase activity in white muscle of fish supplemented with lycopene, compared to the control group (no supplementation). However, catalase activity in red muscle was not altered by supplementation with lycopene, as well as GR activity and LDH in white muscle and red. It was demonstrated that restraint stress increased the plasma cortisol level 
(53\%), level of lipid peroxidation of the fillet (28\%) and activity of CAT, GR and LDH in white muscle $(31 \%, 32 \%$ and $29 \%$, respectively) and red muscle $(48 \%, 46 \%$ and $44 \%$, respectively) of animals subjected to stress. However, dietary supplementation with lycopene abolished the negative effects of stress restraint, avoiding high levels of cortisol, the TBARS content of the fillet and activity of enzymes CAT, GR and LDH in white muscle and red. It was concluded that lycopene aired the commercial feed at a ratio of $800 \mathrm{mg} / \mathrm{kg}$ of diet, reduces the negative effects of stress and does not alter the performance of juvenile Nile tilapia.

Keyword: Oreochromis niloticus, welfare, lycopene, stress, oxidative stress, performance. 


\section{LISTA DE FIGURAS}

Figura 1.- Esquema do delineamento experimental da Etapa 1 38

Figura 2.- Esquema do delineamento experimental da Etapa 2 39

Figura 3 - Efeito da suplementação de juvenis de tilápia do Nilo (Oreochromis niloticus) com licopeno via ração sobre a concentração de substâncias reativas ao ácido tiobarbitúrico (TBARS) avaliado em filé (músculo branco) dos animais do grupo controle e do grupo submetido suplementado por 60 dias com licopeno $(800 \mathrm{mg} / \mathrm{kg}$ de ração). Os resultados estão expressos como média e desvio padrão ( $n=10$ animais/tratamento). Letras iguais não apresentam diferença ao nível de significância de 5\%. .51

Figura 4 - Efeito da adição de licopeno (800 mg/kg de ração) durante 60 dias sobre a atividade de enzimas antioxidantes presentes em músculo branco e vermelho de juvenis de tilápias do Nilo (Oreochromis niloticus). (A) Atividade da catalase e (B) Atividade da glutationa redutase. Resultados expressos como média e desvio padrão ( $n=10$ animais/tratamento). Para cada grupo de músculo, letras diferentes indicam diferença ao nível de significância de 5\% .55

Figura 5 - Efeito da adição de licopeno (800 mg/kg de ração) durante 60 dias sobre a atividade da lactato desidrogenase presente em músculo branco e vermelho de juvenis de tilápias do Nilo (Oreochromis niloticus). Resultados expressos como 
média e desvio padrão ( $n=10$ animais/tratamento). Para cada grupo de músculo, letras iguais não apresentam diferença ao nível de significância de $5 \%$. .57

Figura 6.- Imagem de tilápia do Nilo antes (A) e após estresse de contenção por redução do nível de água $(\mathrm{B})$. .59

Figura 7 - Concentração plasmática de cortisol em juvenis de tilápia do Nilo (Oreochromis niloticus) submetidos a estresse de contenção durante 90 minutos. Resultados expressos como média e desvio padrão ( $n=10$ animais/tratamento). Para cada grupo avaliado, letras diferentes indicam diferença ao nível de significância de $5 \%$ .60

Figura 8 - Efeito da contenção (90 minutos) de juvenis de tilápia do Nilo (Oreochromis niloticus) sobre a concentração de substancias reativas ao ácido tiobarbitúrico (TBARS) na musculatura branca. Resultados expressos como média e desvio padrão ( $n=10$ animais/tratamento). Para cada tratamento avaliado, letras diferentes indicam diferença ao nível de significância de 5\%. .63

Figura 9 - Efeito da contenção (90 minutos) sobre a atividade de enzimas antioxidantes presentes nos músculos brancos e vermelhos de juvenis de tilápias do Nilo (Oreochromis niloticus). (A) Atividade da catalase e (B) Atividade da glutationa redutase. Resultados expressos como média e desvio padrão $(n=10$ peixes/tratamento). Para cada grupo de músculo, letras diferentes indicam diferença ao nível de significância de $5 \%$. 
Figura 10 - Efeito da contenção (90 minutos) sobre atividade de lactato desidrogenase avaliada no músculo branco e vermelho de juvenis de tilápia do Nilo (Oreochromis niloticus). Resultados expressos como média e desvio padrão ( $\mathrm{n}=10$ peixes/tratamento. Para cada grupo de músculo, letras diferentes indicam diferença ao nível de significância de 5\%. 69

Figura 11 - Efeito da suplementação com licopeno (800 mg/kg de ração) sobre os níveis de cortisol plasmático de juvenis de tilápia do Nilo (Oreochromis niloticus) submetidos a estresse de contenção (90 minutos). Resultados expressos como média e desvio padrão ( $n=10$ animais/tratamento) Para cada grupo avaliado, letras diferentes indicam diferença ao nível de significância de 5\% 71

Figura 12 - Efeito da suplementação com licopeno (800 mg/kg de ração) sobre o conteúdo de substâncias reativas ao ácido tiobarbitúrico (TBARS) no músculo branco (filé) de juvenis de tilápia do Nilo (Oreochromis niloticus) submetidos a estresse de contenção (90 minutos). Resultados expressos como média e desvio padrão ( $n=10$ animais/tratamento). Letras diferentes indicam diferença ao nível de significância de 5\%. .75

Figura 13 - Efeito da adição de licopeno (800 mg/kg de ração) durante 60 dias sobre a atividade de enzimas antioxidantes presentes em músculo branco e vermelho de juvenis de tilápias do Nilo (Oreochromis niloticus). (A) Atividade da catalase e (B) Atividade da glutationa redutase e subsequentemente exposto a contenção. Resultados expressos como média e desvio padrão ( $n=10$ animais/tratamento). 
Para cada grupo de músculo, letras diferentes indicam diferença ao nível de

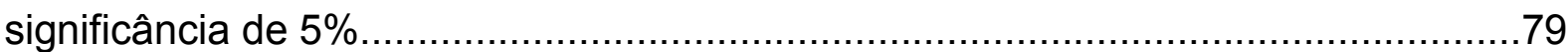

Figura 14 - Efeito da adição de licopeno (800 mg/kg de ração) durante 60 dias sobre a atividade da lactato desidrogenase presente em músculo branco e vermelho de juvenis de tilápias do Nilo (Oreochromis niloticus) e subsequentemente exposto a contenção. Resultados expressos como média e desvio padrão $(n=10$ animais/tratamento). Para cada grupo de músculo, letras diferentes indicam diferença ao nível de significância de 5\%. 81 


\section{LISTA DE TABELAS}

Tabela 1 - Comportamento alimentar de juvenis de tilápia do Nilo alimentados com dietas contendo diferentes concentrações de licopeno ( 0 - controle, 100, 200, 400 e $800 \mathrm{mg} / \mathrm{kg}$ de ração) 46

Tabela 2 - Efeito da suplementação com licopeno sobre o desempenho de juvenis de tilápia do Nilo (Oreochromis niloticus) avaliado no grupo controle e no grupo suplementado por 60 dias com licopeno ( $800 \mathrm{mg} / \mathrm{kg}$ de ração) .49

Tabela 3 - Efeito da suplementação com licopeno sobre a cor do filé (músculo branco) determinada pela luminosidade (L), coeficiente de coloração vermelha (a) e coeficiente de coloração amarela (b) em juvenis de tilápia do Nilo (Oreochromis niloticus)

Tabela 4 - Efeito da contenção (90 minutos) de juvenis de tilápia do Nilo (Oreochromis niloticus) sobre a cor do filé (músculo branco) determinada pela luminosidade (L), coeficiente de coloração vermelha (a) e coeficiente de coloração amarela (b)

Tabela 5 - Efeito da suplementação com licopeno (800 mg/kg de ração) sobre o desempenho de juvenis de tilápia do Nilo (Oreochromis niloticus) submetidos a estresse de contenção (90 minutos) 
Tabela 6 - Efeito da suplementação com licopeno (800 mg/kg de ração) sobre parâmetros de cor instrumental da carne de juvenis de tilápia do Nilo (Oreochromis niloticus) submetidos a estresse de contenção (90 minutos). 


\section{SUMARIO}

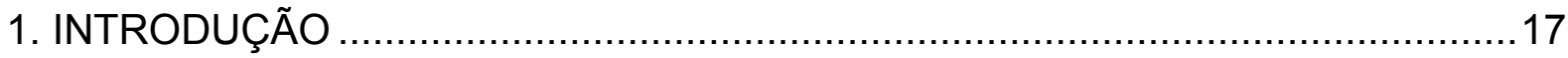

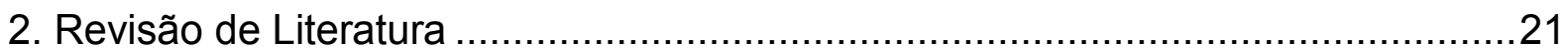

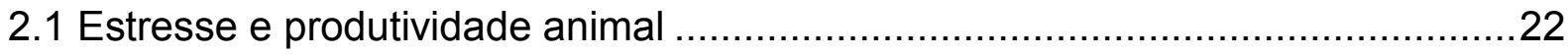

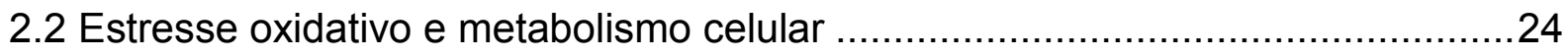

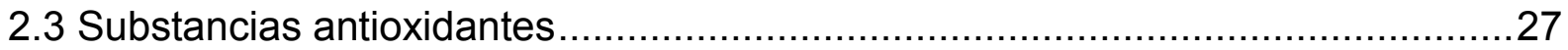

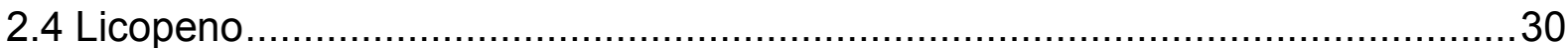

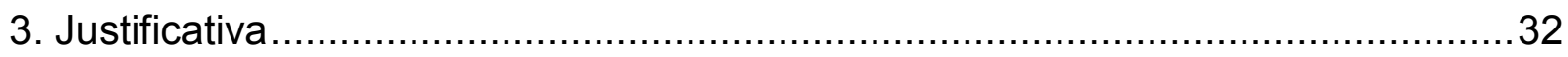

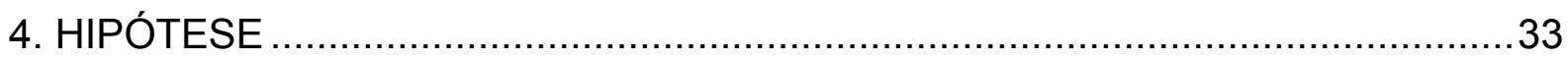

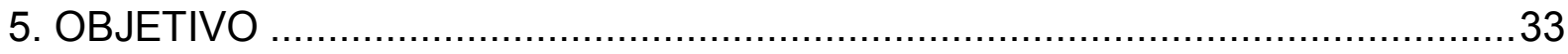

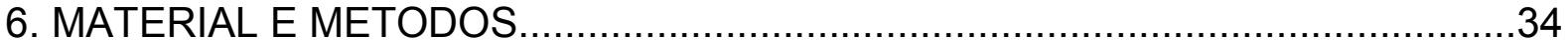

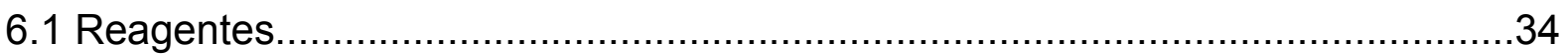

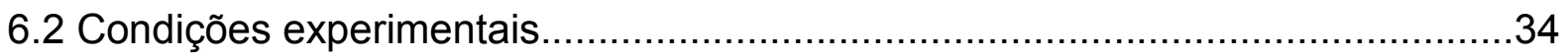

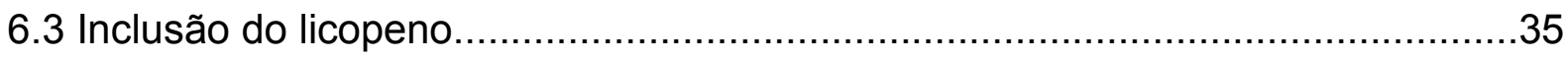

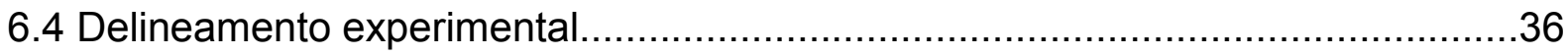

6.4.1 Etapa 1 - Efeito da suplementação com licopeno sobre a atrato-palatabilidade da ração

6.4.2 Etapa 2 - Efeito do licopeno na promoção do bem-estar de juvenis de tilápia do

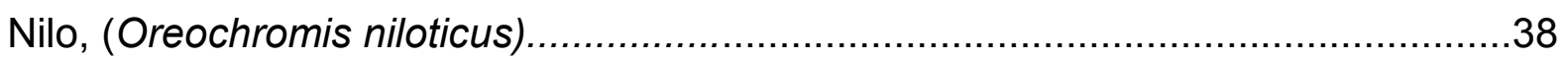

6.4.2.1 Administração do licopeno.........................................................

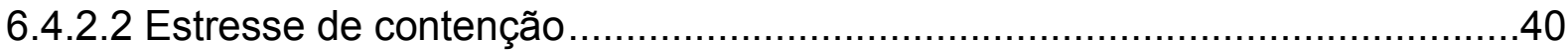

6.4.2.3 Obtenção das amostras de sangue e tecido muscular ..............................40

6.4.2.4 Avaliação de parâmetros de desempenho .........................................41

6.4.2.5 Determinação do cortisol plasmático................................................41 
6.4.2.6 Determinação da atividade das enzimas catalase, glutationa redutase e

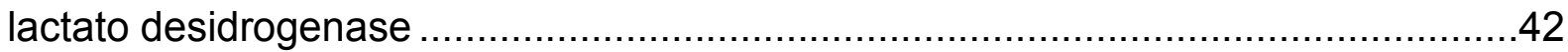

6.4.2.7 Determinação dos níveis de peroxidação lipídica ....................................43

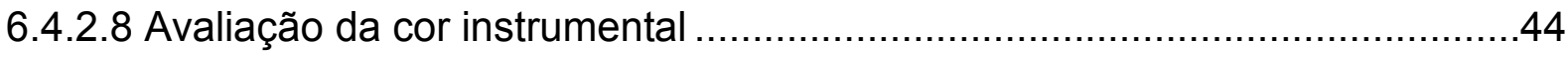

6.4.2.9 Determinação de proteinas totais.....................................................44

6.5 Análise dos resultados ........................................................................... 44

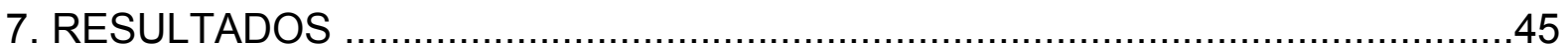

7.1 Etapa 1 - Efeito da suplementação com licopeno sobre a atrato-palatabilidade da ração.

7.2 Etapa 2 - Efeito do licopeno na promoção do bem-estar de juvenis de tilápia do Nilo, (Oreochromis niloticus).

7.2.1 Efeito do licopeno sobre parâmetros zootécnicos e bioquímicos de juvenis de tilápia do Nilo (Oreochromis niloticus) não submetidos a estresse.

7.2.2 Efeitos do estresse por contenção sobre parâmetros zootécnicos e bioquímicos de juvenis de tilápia do Nilo (Oreochromis niloticus). .58

7.2.3 Efeitos do licopeno sobre parâmetros zootécnicos e bioquímicos de juvenis de tilápia do Nilo (Oreochromis niloticus) submetidos a estresse por contenção. .70

8. CONCLUSÕES .83

9. REFERÊNCIAS BIBLIOGRÁFICAS .84 


\section{INTRODUÇÃO}

Nas condições de criação intensiva os peixes são constantemente expostos aos diferentes agentes estressores que ocorrem de forma rápida e aguda ou crônica e continuamente. As altas densidades de estocagem e os manejos como despesca, confinamento para depuração (jejum) e transporte, afetam negativamente a taxa de crescimento e aumentam a susceptibilidade às doenças (COSTAS et al., 2008).

Durante o metabolismo celular normal, espécies reativas de oxigênio (ERO) tais como $\mathrm{O}_{2}^{-}$e a $\mathrm{H}_{2} \mathrm{O}_{2}$ são formadas, pois a redução do oxigênio pela cadeia respiratória mitocondrial não é completa em sua totalidade (HAWLEY, 2002; LINKE et al., 2005). De acordo com Chance e Willians (1956), aproximadamente $3 \%$ do oxigênio consumido pelas mitocôndrias estão associados à produção de ERO.

As ERO têm a capacidade de provocar danos irreversíveis à membrana mitocondrial, inativar várias enzimas e alterar o potencial elétrico transmembrana, resultando em déficit na produção de energia. Além disso, estes compostos provocam danos oxidativos em biomoléculas como os lipídeos, proteínas e DNA (AGARWAL e RAO, 2000).

O acúmulo intracelular das ERO é denominado estresse oxidativo e as células, por meio de enzimas ou moléculas não enzimáticas, controlam estritamente os níveis destes compostos e mantém o equilíbrio entre as moléculas oxidantes e as antioxidantes (AGARWAL e RAO, 2000; HALLIWELL e GUTTERIDGE, 2007).

Vários compostos estão envolvidos no processo de detoxificação do oxigênio reativo, incluindo-se a glutationa, o ascorbato e enzimas especificas como a 
superoxido dismutase, catalase e a glutaniona peroxidase que podem ser quantificadas e, portanto, indicar o nível do estresse oxidativo (CADENAS, 1995).

Os peixes são, também, susceptíveis ao ataque das ERO continuamente geradas pelo metabolismo aeróbio e apresentam sistemas antioxidantes de defesa. Segundo Martinez-Alvarez et al., (2005) a primeira linha de defesa constitui-se por antioxidantes não enzimáticos tais como as vitaminas $\mathrm{C}$ e $\mathrm{E}$, ácido úrico, glutationa $\mathrm{e}$ carotenóides. Além disso, diversas enzimas antioxidantes como a catalase (CAT), superoxido dismutase (SOD), glutationa peroxidade (GPx) e glutationa redutase (GR) prevêem a cascata de reações oxidativas, interceptando e inativando os compostos intermediários do metabolismo do oxigênio (RUDNEVA, 1997; HALLIWELL e GUTTERIDGE, 2007; MARTINEZ-ÁLVAREZ et al., 2005).

O estresse oxidativo em peixes tem sido avaliado por meio da quantificação da atividade das enzimas superoxido dismutase, catalase, glutationa peroxidase e glutationa redutase (ORUC e UNER, 2000; ALMEIDA et al., 2002; BASHA e RANI, 2003; FERREIRA et al., 2005).

Outro parâmetro indicativo de estresse é o nível de oxidação lipídica, evidenciado em organismos aquáticos como caranguejos e peixes (SARGENT et al., 2002; PINHO et al., 2005; SMITH et al., 2007; OLIVEIRA et al., 2008; PENG et al., 2009). Este indicador foi também descrito em trabalhos realizados com tilápias do Nilo (JOS et al., 2005; PRIETO et al., 2007).

Assim como outros organismos, os peixes têm exigências especificas químicas e físicas, que, quando não supridas, promovem um estado de desequilíbrio que afeta seu bem estar e sobrevivência. Animais criados em cativeiro têm uma inerente desvantagem frente aos selvagens, decorrente do confinamento e, portanto, 
é recomendável que os piscicultores reconheçam os sinais de estresse e utilizem protocolos adequados de manejo para reduzir seus efeitos, pois disto depende 0 sucesso econômico (CONTE 2004). A atenção e preocupação com o significado do estresse nas criações intensivas de peixe têm aumentado nos últimos anos, principalmente por seus efeitos negativos sobre a produção (URBINATI e CARNEIRO, 2004).

Antioxidantes têm sido utilizados para reduzir o estresse oxidativo e promover o bem-estar em peixes (TRENZADO et al., 2009). Amar et al. (2000) observaram aumento da resposta imune de trutas alimentadas com ração suplementada com ßcaroteno. As vitaminas C e E são consideradas moderadoras de estresse em peixes (MERCHIE et al., 1997; MONTERO et al., 2001; KOLKOVSKI et al., 2000; ORTUÑO et al., 2003).

A deficiência de vitamina $E$ nas dietas de peixes submetidos a estresse provoca uma baixa resistência, elevação de cortisol, alterações hematológicas e imunológicas e uma diminuição na taxa de crescimento e sobrevivência (CHEN et al., 2004; BELO et al., 2005). Os efeitos desta vitamina sobre as defesas antioxidantes têm sido investigados em várias espécies de peixes (LYGREN et al., 2000; MOURENTE et al., 2002; TOCHER et al., 2002; TRUSHENSKI et al., 2007; MARTINS et al., 2007).

Dentre os produtos naturais com potencial antioxidante encontra-se 0 licopeno, carotenóide encontrado em vegetais como o tomate, melancia, pimenta vermelha e uvas, conferindo-lhes a coloração vermelha (HAKALA e HEINONEN, 1994; WEISBURGER, 1998; BEN-AMOTZ e FISHLER, 1998; NGUYEN, et al., 1999; 
THOMPSON et al., 2000). Porém, não há referências na literatura sobre seu uso na promoção do bem-estar em peixes.

O objetivo deste trabalho foi avaliar os efeitos da suplementação com licopeno na ração comercial sobre o desempenho e parâmetros fisiológicos e bioquímicos indicadores de estresse em juvenis de tilápias do Nilo (Oreochromis niloticus). 


\section{REVISÃO DA LITERATURA}

A inspeção do plantel de animais na aquicultura faz parte da rotina de trabalho e este constante monitoramento pode ajudar a identificar sintomas de enfermidades ou doenças e crescimento heterogêneo que são características não desejáveis do ponto de vista econômico. Assim, a ação tomada após esta observação necessariamente afeta todo o plantel do tanque ou viveiro, já que todos os animais terão que ser capturados para classificação e posterior tratamento.

Qualquer operação que envolva manuseio de animal pode causar esforço e consequente estresse e dano físico, o que pode reduzir o apetite e retardar o crescimento, tornando o animal mais susceptível às doenças (LINE E FROST, 1999).

Em contraste com a maioria de outras formas de criação de animais, existe uma escassez de informações científicas sobre o bem estar de peixes cultivados, o que induz um manejo inadequado trazendo prejuízo na produção. Dados anatômicos, farmacológicos e de comportamento sugerem que o estado afetivo de dor, medo e estresse dos peixes seja provavelmente experimentado de maneira semelhante aos tetrápodes, ou seja, os peixes têm a capacidade de sentir dor (nocicepção) e considerações sobre seu bem estar devem ser levadas em conta no intuito de um correto manejo (SNEDDON, 2003; CHANDROO et. al, 2004; BRAITHWAITE e BOULCOTT, 2007).

Um número considerável de estudos discute a importância do bem estar em diferentes grupos animais, como suínos, aves, gado de corte e leiteiro (DUNCAN, 2006; DAWKINS, 2008; BROOM, 2008; BEKOF, 2008; FRASER, 2008; HOGAN e 
PHILLIPS, 2008; VEISSIER E FORKMAN, 2008; YEATES e MAIN, 2008; VOLPATO et. al., 2009). Abordagens sobre a percepção da dor e a consciência animal (senciência) são também descritas para os peixes (BALON, 2000; ROSE, 2002; CHANDROO et. al., 2004; CONTE, 2004, HASTEIN et. al., 2005; HUNTINGFORD et. al., 2006; VOLPATO et. al., 2007; GÓMEZ-LAPLAZA e GIL-CARNICERO, 2008).

\subsection{Estresse e produtividade animal}

O estresse caracteriza-se por um desequilíbrio fisiológico que desencadeia uma série de respostas provenientes do sistema nervoso central o qual capta o estímulo estressor, e do sistema hormonal, que organiza a defesa biológica, a chamada resposta ao estresse (BARTON e IWAMA, 1991). O estresse agudo caracteriza-se por dois tipos de respostas fisiológicas, uma primária ou de alarme, hormonal e resultante do estímulo do sistema nervoso simpático e do eixo hipotálamo-hipófise-interrenal, e uma secundária ou de resistência, caracterizada por um conjunto de diferentes mecanismos, responsáveis pelo ajuste fisiológico do peixe (MAZEUD e MAZEUD, 1981).

Outro tipo de estresse é o social, acentuado nas condições de cativeiro e que prejudica também a produção. Espécies territoriais como a tilápia do Nilo, Oreochromis niloticus, apresentam hierarquia de dominância e submissão, estabelecida por meio de confrontos agonísticos entre os animais maiores, dominantes e os menores, submissos, que são mais prejudicados (FERNANDES, 1997). Segundo Volpato et al (1987) animais hierarquicamente submissos desta espécie apresentam aumento da atividade metabólica, comparativamente aos dominantes e, portanto, reservas energéticas destinadas ao crescimento são 
desviadas para atender às demandas metabólicas impostas pelo estresse decorrente das interações agonísticas. Além disso, estes indivíduos manifestam uma reação fisiológica antes mesmo dos confrontos, o que sugere que a visão dos coespecíficos seria suficiente para promover tais alterações.

As respostas dos peixes aos agentes estressores são também classificadas em agudas (primárias), crônicas (secundárias) e crônicas prolongadas (terciárias). Segundo Pickering (1981), as agudas envolvem ativação do sistema neuroendócrino resultando na liberação de catecolaminas e hormônios corticosteróides; as crônicas incluem respostas fisiológicas a estes hormônios, como aumento do débito cardíaco, do consumo de oxigênio e mobilização de reservas energéticas; as crônicas prolongadas promovem a inibição do crescimento, da reprodução e das respostas imunes. Os peixes possuem capacidade natural de responder fisiologicamente ajustando-se às alterações comuns do habitat natural, porém um estresse crônico impossibilita tal capacidade afetando a produtividade em uma piscicultura (BONGA, 1997; BARTON e IWANA, 1991).

O aumento dos níveis de cortisol plasmático caracteriza-se como uma resposta primária, enquanto que, as alterações dos níveis plasmáticos da glicose e níveis hepáticos do glicogênio e o metabolismo de lipídeos e proteínas relacionamse às respostas secundárias (MORATA et al., 1982; HEMRE e KROGDAHL, 1996). O cortisol é um hormônio corticosteróide que aumenta após a exposição aguda ou crônica do peixe a um agente estressor, podendo desencadear atividade neoglicogênica e estímulo da mobilização de aminoácidos e de lipídios que serão utilizados como substratos energéticos, fato que afeta indiretamente o crescimento (LEACH e TAYLOR, 1982; DAVIS et al., 1985; SHERIDAN, 1986; VIJAYAN e LEATHERLAND, 1989; VIJAYAN et al., 1994 a,b). 
Mudanças nos níveis das catecolaminas, assim como dos hormônios corticosteróides como o cortisol, são utilizadas para monitoramento de respostas aos agentes estressores. Porém, o cortisol tem sido mais frequentemente usado, devido à possibilidade de utilização de kits comerciais práticos, seguros e de baixo custo, ao contrário do que se verifica para as catecolaminas (REDDY e LEATHERLAND, 1998).

Segundo Wendelaar (1997) processos metabólicos anaeróbios resultantes de uma atividade extrema (estresse crônico) promovem o acúmulo de ácido lático na musculatura ou sangue dos peixes (hiperlactemia), o que pode ser também utilizado como indicador do estresse. Estudos recentes demonstraram que no músculo branco dos peixes ocorre principalmente a glicólise anaeróbia para suprir necessidades energéticas, enquanto que na musculatura vermelha predominam vias aeróbias, incluindo a alta atividade do ciclo do ácido cítrico e fosforilação oxidativa (BERNAL et al., 2003; MCKENZIE et al., 2004; CLUTTERHAM et al., 2004; DALZIEL et al., 2005).

\subsection{Estresse oxidativo e metabolismo celular}

O estresse oxidativo é caracterizado pelo desequilíbrio entre a formação de espécies reativas e a capacidade de defesa celular contra estas espécies, favorecendo as espécies reativas (AMSLAD et al, 1994; CORNELIUS et al, 1993; CADENAS e DAVIES, 2000).

As espécies reativas no meio celular podem ser geradas a partir de várias fontes tais como radiação solar, metabolismo de leucócitos, reações metabólicas 
intra e extracelulares e, principalmente, pelo metabolismo do oxigênio. $\mathrm{Na}$ mitocôndria durante a respiração aeróbia, ocorre a redução completa do oxigênio à água, acompanhada de uma alta liberação de energia vital para a célula; porém, estima-se que aproximadamente $3 \%$ do oxigênio consumido tenha sua redução incompleta formando as espécies reativas de oxigênio (ERO) (HALLIWELL e GUTTERIDGE, 2007).

As ERO mais importantes, do ponto de vista biológico, são os radicais livres ânion superóxido $\left(\mathrm{O}_{2}^{-*}\right)$ e hidroxil $\left({ }^{\circ} \mathrm{OH}\right)$, que são moléculas com um elétron não pareado ocupando a camada de valência. Outra ERO bastante oxidante é o peróxido de hidrogênio $\left(\mathrm{H}_{2} \mathrm{O}_{2}\right)$, que embora não possuindo elétrons desemparelhados na camada de valência a sua alta reatividade é conferida principalmente por sua estabilidade relativa (DRÖGE, 2002).

As consequências negativas devidas ao estresse oxidativo são inúmeras, tais como danos moleculares às estruturas celulares que alteram a sua funcionalidade e prejudicam as funções vitais (DRÖGE, 2002). Estes danos podem ser observados em diversos tecidos e órgãos tais como fígado, músculo e tecido adiposo (BARJA DE QUIROGA, 1992; GOLDFARB, 1993), vascular (DUARTE et al., 1993; FENSTER et al., 2002) e cerebral (SIGNORINI e SIGNORINI, 1993; HALLIWEL, 1994; KEYNES; GARTHWAITE, 2004).

As células possuem mecanismos de defesa contra as ERO realizados por meio de moléculas e/ou enzimas (SIES, 1993). O sistema não enzimático pode ser classificado em endógeno (bilirrubina, melatonina, ácido úrico, coenzima-Q e outros produtos metabólicos) e exógeno ( $\alpha$-tocoferol, ácido ascórbico, polifenóis, selênio e outros obtidos através da dieta) (HALLIWELL e GUTTERIDGE, 2007). O sistema 
enzimático é constituído por uma série de enzimas, tais como a superóxido dismutase (SOD), catalase (CAT), glutationa peroxidase (GPx) e glutationa redutase (GR) (HALLIWELL e GUTTERIDGE, 2007). Desta forma, na linha de proteção que atua como detoxificadora dos agentes oxidantes antes de causar a lesão celular estão as enzimas SOD, CAT, GPx e os metabólitos glutationa reduzida (GSH), e vitamina E; e na linha de defesa que tem a função de reparar a lesão ocorrida estão as enzimas GR e GPx e os metabólitos ácido ascórbico e GSH (FERREIRA et al., 1997; RODRIGUEZ et al, 2004).

A adaptação frente a vários tipos de estresse é uma característica notável de mamíferos que, segundo Dröge (2002) e Urso e Clarkson (2003), têm a capacidade de ativar um sistema antioxidante quando estão expostos a um estresse oxidativo, mantendo assim sua homeostase. Estudos relacionados ao estresse oxidativo e às defesas antioxidantes em peixes têm sido descritos recentemente na literatura tomando como biomarcadores de estresse o aumento significativo dos níveis de peroxidação lipídica e da atividade das enzimas antioxidantes (BELL et al. 2000; TOCHER et al. 2002; LIVINGSTONE, 2003; ABELE e PUNTARULO, 2004; PALACE e WERNER, 2006; ASHIDA et al. 2006). Os mesmos efeitos são descritos quando utilizadas substâncias poluentes e tóxicas sobre a atividade de enzimas antioxidantes, em organismos aquáticos, particularmente em peixes. Dentre os poluentes podem ser citados, metais pesados, inseticidas, e dentre as substâncias tóxicas, toxinas, altas doses de antibióticos, entre outros (VINAGRE et al., 2003; PINHO et al., 2005; CAZENAVE et al., 2006; MONSERRAT et al., 2007; FERRARI et al., 2007; PRIETO et al., 2007; OLIVEIRA et al., 2008; MONSERRAT et al., 2008 e LEÃO et al., 2008). 


\subsection{Substâncias antioxidantes}

Devido aos danos decorrentes do estresse oxidativo, há um crescente interesse no uso de antioxidantes exógenos que consigam proteger os organismos, principalmente os provenientes de alimentos naturais como frutas e plantas. Segundo CHUN et al. (2005), o processo de retardamento do câncer e demais doenças crônicas está relacionado com importantes funções de vários compostos antioxidantes presentes na dieta como, por exemplo, as vitaminas C e E.

As plantas possuem substâncias como taninos, fenóis, alcalóides, ligninas, cafeínas e aminas que atuam como antioxidantes (LARSON 1988; COTELLE, 1996; OKADA et al., 1996). Desta forma, a propriedade antioxidante de eliminar radicais livres e/ou espécies reativas e quelar metais reativos é atribuída a alguns compostos fenólicos de plantas (CHUN et al., 2005).

Ervas como o orégano, alecrim, tomilho e menta apresentam atividade antioxidante relacionada à presença de altas concentrações de compostos fenólicos. Estudos realizados com o óleo de orégano demonstraram ação antimicrobiana a Helicobacter pylori, bactéria estomacal responsável por um tipo crônico de gastrite em humanos (CHUN et al., 2005). Melo et al., (2003) observaram que o coentro Coriandrum sativum $L$, especiaria muito usada no Brasil, possui tanto em seu extrato etéreo como no extrato aquoso um grande potencial antioxidante, atribuído principalmente aos carotenóides e aos compostos fenólicos. Segundo Menezes (2005), a própolis também é um composto natural que contém em sua composição polifenóis e outros compostos com a propriedade de remover radicais livres em excesso, conferindo-lhe atividade antioxidante. 
A atividade antioxidante de compostos orgânicos é atribuída às suas estruturas moleculares que, geralmente, possuem grupamentos fenólicos como flavonóides e fenilpropanóides, além de outros compostos aromáticos (CHUN et al., 2005). Dentre os vegetais que apresentam compostos antioxidantes naturais destacam-se, também, as folhas de Maytenus aquifolium, uma espécie de árvore selvagem proveniente do cerrado brasileiro e que é amplamente utilizada no tratamento de úlcera gástrica. Corsino et al. (2003) observaram que suas folhas em forma de infusões apresentam ação antioxidante, protegendo a mucosa estomacal das espécies reativas de oxigênio formadas no processo crônico da gastrite e posterior úlcera gástrica.

Os antioxidantes naturais também são estudados para a quimioprevenção do câncer, assim o guaraná Paullinia cupana, planta originária do Brasil, possui alta concentração de tanino, produto secundário do metabolismo de várias plantas e que pode suprimir a carcinogênese química induzida pelo $N$-nitrosodietilamina (DESHPANDE et al., 1984; FUKUMASU et al., 2006).

Estudos realizados com animais de criação têm demonstrado os efeitos benéficos da suplementação de dietas com antioxidantes sobre a produção e a qualidade dos produtos gerados. Alves (2006) constatou que antioxidantes prolongam a coloração adequada e aumentam a vida de prateleira da carne de suínos alimentados com dietas suplementadas com selênio, principalmente se este produto for fornecido ao leitão recém nascido.

Outros autores têm desenvolvido estudos de suplementação com antioxidantes nas dietas de outros animais de interesse comercial. Assim, segundo Paschoal et al. (2006) e Castillo et al., (2005), a adição de antioxidantes como 
vitamina $A$, vitamina $E$ ( $\alpha$-tocoferol), vitamina D3 e selênio na dieta de bovinos leiteiros, reduzem o nível de produtos da peroxidação lipídica no leite. Havemose et al. (2004) observaram que a suplementação com vitamina $E, \beta$-caroteno, luteína e zeaxantina pode retardar a oxidação de proteínas no leite bovino. Politis et al. (1995), Ndiweni e Finch, (1996) e Valle (2005) observaram que a suplementação da dieta de vacas leiteiras, no pré e pós parto, com vitamina E, melhora a atividade das células fagocitárias, prevenindo a incidência de mastite clínica.

A suplementação na dieta de animais de corte com antioxidantes como vitamina $E$, vitamina $C$ e ácido lipóico, promove significativa melhora na conservação da carne, fato atribuído por vários autores à maior estabilidade da cor e menor oxidação dos lipídeos (LAURIDSEN et al. 1999; HARRIS et al., 2001; ROWE et al., 2004; RENTFROW et al., 2004; BEKHIT et al., 2005).

Com a finalidade de reduzir o estresse oxidativo e promover o bem-estar em peixes, alguns estudos com antioxidantes, como o selênio e as vitaminas $C$ e $E$ tem verificado efeitos positivos (AMAR et al., 2000; AL-BANDAK, 2009; TRENZADO et al., 2009).

Uma linha importante para a pesquisa atual pode estar constituída por estudos com suplementação alimentar com antioxidantes naturais, devido aos resultados promissores na produtividade animal. Neste contexto a busca por novos compostos com atividades antioxidantes torna-se importante. 


\subsection{Licopeno}

Com a finalidade de promover o bem-estar nos peixes, podem ser empregadas substâncias anestésicas, drogas hipnóticas ou produtos naturais que combatem o estresse metabólico e aumentam a taxa de sobrevivência, reduzindo o metabolismo e o consumo de oxigênio. Dentre os produtos naturais destaca-se o licopeno, um dos mais de 600 carotenóides encontrados em vegetais como o tomate, pimenta vermelha, melancia e uvas, proporcionando-lhes sua coloração vermelha (HAKALA e HEINONEN, 1994; BEN-AMOTZ e FISHLER, 1998; THOMPSON et al, 2000). O licopeno é um antioxidante com capacidade de se unir às $\mathrm{ERO}$, motivo pelo qual tem despertado interesse nas pesquisas, realizadas principalmente em humanos (SHI et al., 1999, VELMURUGAN et al., 2004; TAPIERO et al., 2004; COHEN, 2002; JONKER et al., 2003; MICHAEL MCCLAIN e BAUSCH, 2003).

Estudos realizados com licopeno após o tratamento com calor durante o processo de elaboração de subprodutos de tomate demonstraram sua estabilidade termodinâmica (TOMA et al., 2008). De acordo com Boileau et al. (1999); Rao e Agarwal (2000); Shi (2000), Arab e Steck (2000) e Stahl e Sies (1996) o alto poder antioxidante decorre do fato de sua molécula, de caráter lipofílico, ser altamente insaturada por duplas ligações. De acordo com pesquisas realizadas em mamíferos roedores, esta molécula pode doar elétrons para suprimir e neutralizar as ERO, consideradas fonte de envelhecimento e a causa de várias doenças degenerativas, antes que elas prejudiquem as células (AGARWAL e RAO, 2000; LIVNY et al, 2002; PAETAU et al., 1998). Os pesquisadores acreditam que o estresse oxidativo é um fator importante para o início e desenvolvimento de arteriosclerose, câncer, catarata, 
artrite e outras doenças degenerativas entre os humanos (MICOZZI, et al., 1994; LEVY et al., 1995; BRAMLEY, 2000). Di Mascio et al. (1989) demonstraram que o licopeno tem maior capacidade de capturar as moléculas de oxigênio singlete, comparativamente a outros pigmentos como o $\alpha$-caroteno, $\beta$-caroteno e $\alpha$ tocopherol. Devido à sua estrutura química, o licopeno é um eficiente supressor biológico das ERO, especialmente aqueles derivados de oxigênio. Porém, apesar de todas estas considerações, nenhuma referência sobre o uso potencial do licopeno em peixes é encontrada na literatura. 


\section{JUSTIFICATIVA}

Embora a maioria dos efeitos negativos do estresse sobre os peixes mantidos nas condições de criação intensiva sejam inevitáveis, é possível e necessário buscar alternativas de manejo que minimizem os impactos sobre a produção.

O aprimoramento de técnicas de manejo é de extrema importância, não só na produção intensiva, mas também nas condições de laboratório, onde a magnitude do estresse e o tempo de recuperação apropriado (aclimatação) antes do início de qualquer pesquisa devem ser considerados (PICKERING, 1981).

Apesar da seleção de linhagens menos susceptíveis ao estresse ser adotada na piscicultura como uma das inúmeras técnicas que visam o aumento da produção, novas alternativas devem ser buscadas. Neste sentido, o licopeno, já empregado com êxito na promoção do bem-estar em mamíferos, principalmente em humanos, surge como uma nova perspectiva para investigação de seu uso potencial em peixes. 


\section{HIPÓTESE}

O licopeno reduz os efeitos negativos do estresse e melhora o desempenho e qualidade do filé de juvenis da tilápia do Nilo, Oreochromis niloticus.

\section{OBJETIVO}

Avaliar os efeitos protetores do licopeno veiculado na dieta comercial sobre o desempenho, estresse fisiológico e bioquímico de juvenis de tilápia do Nilo (Oreochromis niloticus). 


\section{MATERIAL E MÉTODOS}

\subsection{Reagentes}

Os reagentes utilizados nos experimentos apresentados neste trabalho foram todos de grau analítico adquiridos da Sigma-Aldrich (St. Louis, MO, USA).

\subsection{Condições Experimentais}

O estudo foi conduzido entre setembro de 2006 e julho de 2007 no Laboratório de Comportamento de Peixes (LACOPE) e as análises bioquímicas posteriores realizadas no Laboratório de Química Biológica da Faculdade de Zootecnia e Engenharia de Alimentos (FZEA), Universidade de São Paulo (USP), Campus de Pirassununga.

Juvenis machos de tilápia do Nilo, Oreochromis niloticus, com peso médio de $63,47 \pm 3,9 \mathrm{~g}$ e obtidos em piscicultura comercial (Piscicultura Analândia - SP), foram alojados em 50 aquários de vidro (unidades experimentais) com capacidade para $27 \mathrm{~L}(30 \times 30 \times 30 \mathrm{~cm})$, onde permaneceram química e visualmente isolados durante 15 dias para aclimatação às condições laboratoriais.

Cada unidade experimental foi revestida por lâminas de isopor (isolamento térmico e visual) e abastecida com água proveniente de um reservatório central provido de sistema de aquecimento, oxigenação e filtragem biológica. A temperatura da água foi mantida em $26{ }^{\circ} \mathrm{C}$ por meio de aquecedores de $30 \mathrm{~W}$, acoplados a um controlador central (Shiruba H-800 Therm Controller), mantendo-se a oxigenação por meio de compressores externos individuais e um fotoperíodo artificial de 12 
horas utilizando-se lâmpadas fluorescentes acionadas às 6:00h e controladas por timer.

O alimento consistiu de ração comercial extrusada contendo $32 \%$ proteína bruta (PB) (Socil - Evialis Nutrição Animal Ind. Com. Ltda - Laguna Tilápia Crescimento), fornecida diariamente (9:00h) até aparente saciedade. Os peletes foram oferecidos até que, após 10 observações sucessivas num intervalo de 90 minutos, fosse verificada a rejeição pelos peixes.

Cada unidade experimental foi submetida a uma manutenção de limpeza diária que consistiu na aspiração de restos alimentares e excretas seguida pela substituição de $50 \%$ do volume da água. Os indivíduos foram considerados aclimatados quando constatadas características indicativas de bem-estar, tais como coloração pálida do corpo e dos olhos (VOLPATO et al. 2001).

Diariamente foram verificados dados de temperatura e semanalmente as concentrações de oxigênio, amônia e nitrito dissolvidos, utilizando-se respectivamente sonda multiparamétrica (Horiba, Water Quality Checker U-10) e kits colorimétricos (Hanna Instruments, Brasil).

\subsection{Inclusão do licopeno na ração}

Para cada 100 gramas da ração comercial foram dissolvidos $0,5 \mathrm{~g}$ de alginato de sódio (Synth - Lote A1089.01 AS) em $50 \mathrm{~mL}$ de água destilada, agitando-se (agitador magnético) por aproximadamente 45 minutos e completando-se com água destilada até perfazer $100 \mathrm{~mL}$ de solução. Foram pipetados $10 \mathrm{~mL}$ dessa solução, misturando-se (grupo experimental) ou não (grupo controle) a quantidade 
estabelecida de licopeno em pó (BASF® - Lote 81094788Q0) para obtenção das concentrações: 100, 200, 400 e 800 mg/kg de ração. A solução obtida foi aspergida sobre a ração contida em sacos plásticos, agitando-se vigorosamente para uma melhor adsorção do licopeno.

Após a secagem, realizada em temperatura ambiente durante 24 horas, a ração foi mantida sob refrigeração $\left(18^{\circ} \mathrm{C}\right)$, em frascos revestidos com alumínio para prevenção da oxidação do licopeno. Por meio de espectrofotometria visível segundo método de Rodriguez-Amaya (2001) foi feita a análise da ração, e a quantidade de licopeno foi calculada com base na seguinte formula:

Concentração de licopeno $(\mathrm{mg} / \mathrm{kg})=\left(\mathrm{A} \times \mathrm{V} \times 10^{6}\right) /\left(\mathrm{A}^{1 \%} \times \mathrm{m} \times 100\right)$

$A=$ absorbância em $470 \mathrm{~nm}$

$\mathrm{V}=$ volume final em mililitros

$A^{1 \%}=$ coeficiente de absorção do licopeno em éter de petróleo $=3450 \mathrm{~cm}^{-1}$

$\mathrm{m}=$ massa final em gramas

\subsection{Delineamento Experimental}

O experimento foi realizado em duas etapas, que compreenderam primeiramente a avaliação da viabilidade de inclusão e da atrato-palatabilidade da ração contendo diferentes concentrações de licopeno veiculado em alginato de sódio e, posteriormente, a avaliação dos efeitos da adição de licopeno sobre o consumo de alimento, desempenho e parâmetros bioquímicos de juvenis de tilápia do Nilo. 


\subsubsection{Etapa 1 - Efeito da suplementação com licopeno sobre a atrato- palatabilidade da ração}

Foram estabelecidos cinco tratamentos caracterizados pela ausência (controle) ou inclusão do licopeno em diferentes concentrações (100, 200, 400 e 800 $\mathrm{mg} / \mathrm{kg}$ de ração) veiculado em alginato de sódio numa ração comercial extrusada (Socil - Evialis Nutrição Animal Ind. Com. Ltda - Laguna Tilápia Crescimento $32 \% \mathrm{~PB})$.

Cinco peixes $(133,8 \pm 1,2 \mathrm{~g})$ foram aclimatados durante uma semana às condições laboratoriais caracterizadas pelo isolamento visual e químico, fotoperíodo de 12 horas, temperatura de $26{ }^{\circ} \mathrm{C}$ e alimentação até aparente saciedade, duas vezes ao dia, em unidades experimentais de 50 L. Após a aclimatação os animais receberam diária e aleatoriamente, durante 15 dias, 10 grânulos de cada tratamento (teste e controle) oferecidos simultaneamente e ao acaso em dois comedouros circulares de material plástico fixados na superfície em lados opostos dos aquários (Figura 1). Durante 15 dias, cada tratamento foi confrontado com a dieta controle durante 15 minutos, totalizando-se 15 repetições para cada aquário. Registraram-se os seguintes parâmetros indicadores do comportamento alimentar: freqüência de visitas aos comedouros (durante e após o consumo total da ração) e consumo total de grânulos. 


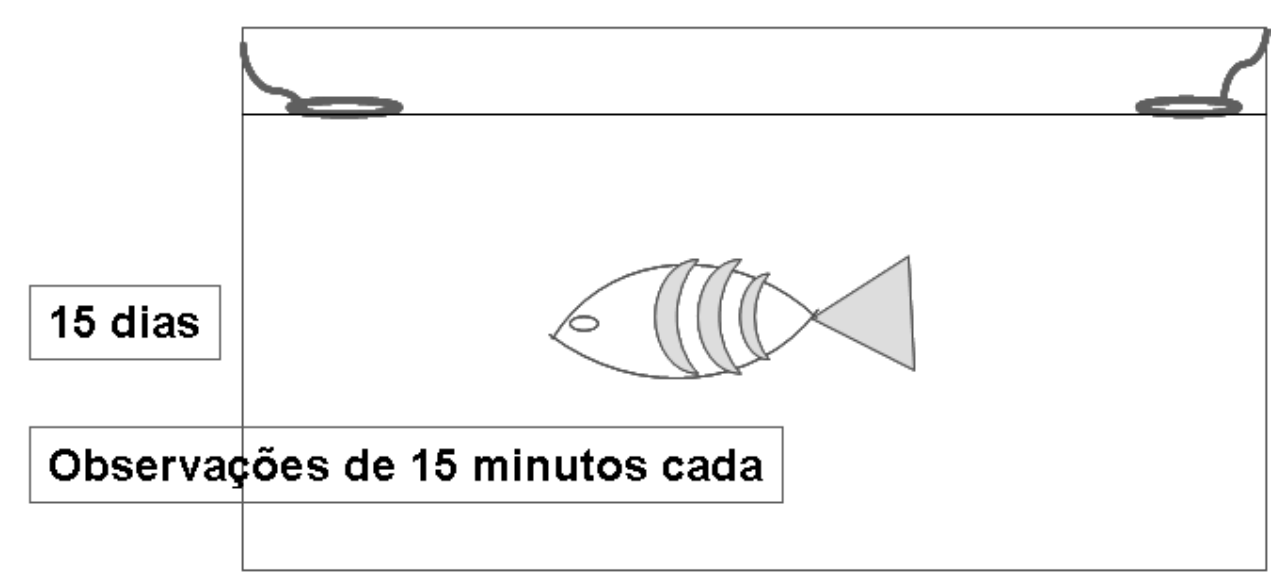

\section{5 peixes $\rightarrow 133,8 \pm 1,2 \mathrm{~g}$}

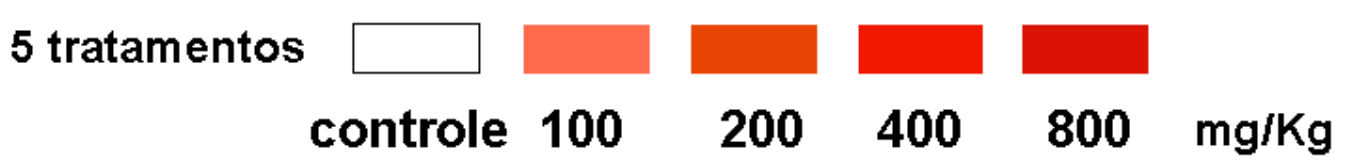

Figura 1.- Esquema do delineamento experimental da Etapa 1.

\subsubsection{Etapa 2 - Efeito do licopeno na promoção do bem-estar da tilápia do Nilo, (Oreochromis niloticus)}

Após a aclimatação foi realizada a biometria e a coleta de sangue visando à determinação dos níveis iniciais de cortisol e a seguir os peixes foram submetidos durante 60 dias a dois tratamentos caracterizados pelo oferecimento da ração comercial acrescida somente de alginato de sódio (grupo controle; $n=20$ animais) ou licopeno veiculado em alginato de sódio (grupo experimental; $n=20$ animais), anotando-se o consumo diário de ração (grânulos)

Como apresentado na Figura 2, ao final do experimento 10 animais de cada grupo foram aleatoriamente submetidos a um estresse de contenção durante 90 
minutos e imediatamente procedeu-se à coleta de sangue de todos os peixes do experimento para determinação dos níveis finais de cortisol. Após este procedimento foi feita a biometria, e posteriormente todos os peixes foram eutanasiados por secção da medula espinhal para realização e remoção de tecido muscular para avaliação das características físico-químicas da carne (índice de cor e peroxidação lipídica) e atividade de enzimas do metabolismo celular.

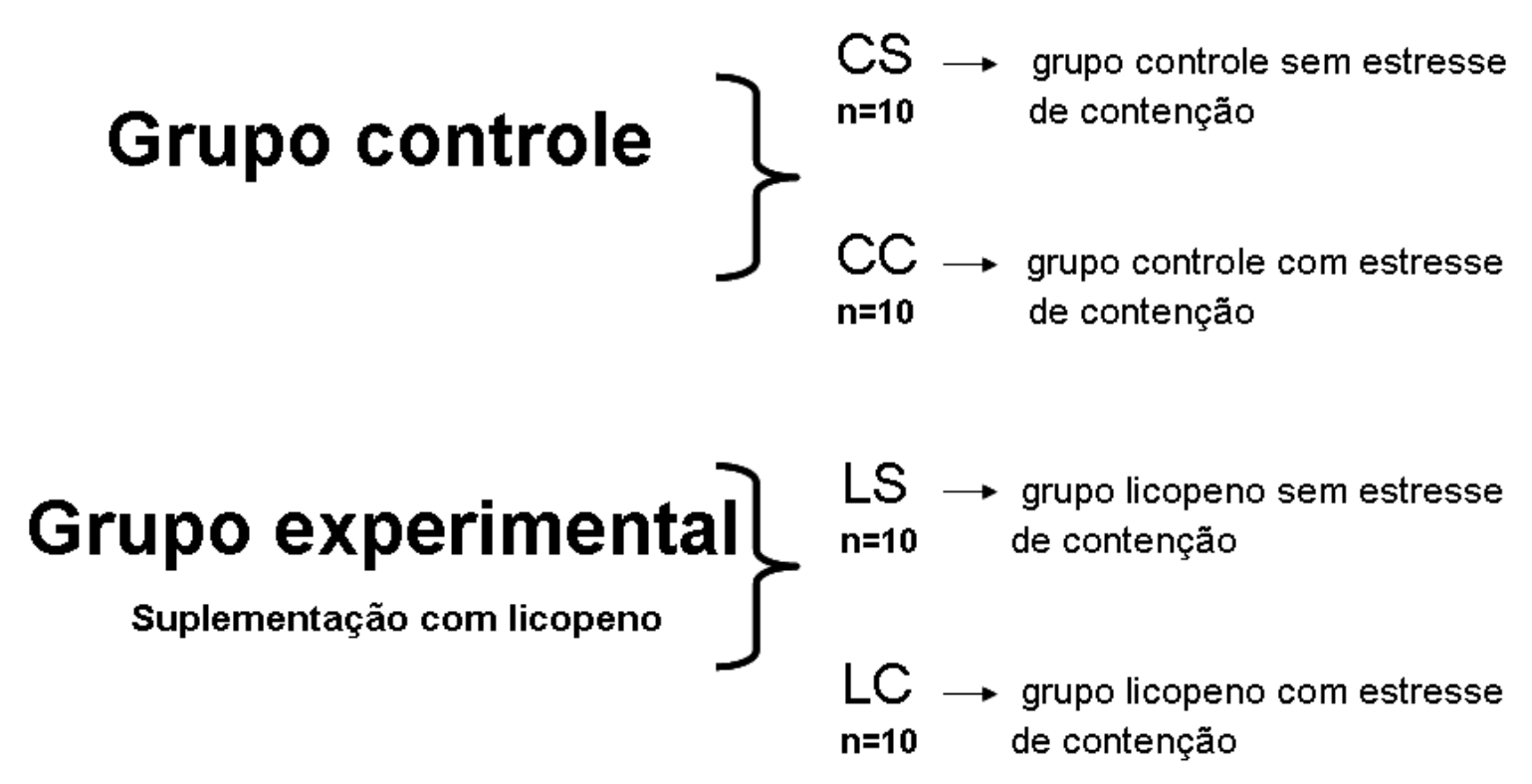

Figura 2.- Esquema do delineamento experimental da Etapa 2.

\subsubsection{Administração do licopeno}

Os animais do grupo experimental receberam durante 60 dias ração comercial extrusada (32\% PB) contendo licopeno (800 mg/Kg de ração) veiculado em alginato 
de sódio, enquanto o grupo controle recebeu ração com adição apenas de alginato de sódio.

\subsubsection{Estresse de contenção}

Adotou-se como agente estressor padrão a contenção dos peixes durante 90 minutos em espaço restrito após redução do nível da coluna da água, o que promoveu a exposição da nadadeira dorsal dos peixes na superfície (GUERRIERO et. al., 2002).

\subsubsection{Obtenção das amostras de sangue e tecido muscular}

Após o período experimental todos os animais foram capturados e anestesiados em solução de óleo de cravo (100\% concentração /15 gotas/L de água) - "Eugenol" (Homeopatia Ouro Preto - Pirassununga, SP;) durante dois minutos para realização da biometria e coleta de sangue $(0,5 \mathrm{~mL})$ por punção da veia caudal, em seringas heparinizadas (insulina $-1 \mathrm{~mL}$ ). As amostras de sangue coletadas foram transferidas para tubos Eppendorf e mantidas refrigeradas $\left(4^{\circ} \mathrm{C}\right)$ até centrifugação (15 min a $3.500 \mathrm{rpm}-4^{\circ} \mathrm{C}$; HETTICH ROTINA 35-R) para separação e congelamento do plasma visando a posterior determinação dos níveis plasmáticos de cortisol.

A seguir todos os peixes foram mortos por decapitação para remoção de amostras de músculo epaxial branco e vermelho (dorso lateral esquerdo) que foram acondicionadas em papel alumínio, identificadas e mantidas em nitrogênio líquido 
para posterior determinação da atividade da catalase, glutationa redutase e lactato desidrogenase.

Amostras de filé (músculo branco) foram removidas, sendo uma parte acondicionada em nitrogênio liquido para posterior determinação do nível de peroxidação lipídica e outra imediatamente refrigerada para avaliação da cor após 24 horas.

\subsubsection{Avaliação de parâmetros desempenho}

Os parâmetros de desempenho foram avaliados a partir de dados coletados no primeiro dia (após o período de aclimatação) e no ultimo dia do experimento.

Por meio dos registros de consumo total de alimento (g/peixe) e ganho em peso $(\mathrm{GP}=$ peso final - peso inicial) $(\mathrm{g})$ foram calculados os seguintes indicadores de desempenho: conversão alimentar $(C A=$ consumo em matéria seca/ganho em peso), fator de condição ( $\mathrm{FC}=$ peso/comprimento ${ }^{3}$ ) e taxa de crescimento específico [TCE= $100 \times($ Ln peso médio final - Ln peso médio inicial)/dias $](\%)$.

\subsubsection{Determinação do cortisol plasmático}

Foi empregado kit comercial para análise do cortisol plasmático (método imuno-enzimático DSL-10-2000 ACTIVE® CORTISOL EIA lote716218), realizandose as leituras por meio de leitor Elisa (Labsystem Multiskan MS) localizado no Laboratório de Fisiologia Animal do Departamento de Ciências Básicas da FZEA/USP. 


\subsubsection{Determinação da atividade das enzimas catalase, glutationa redutase e lactato desidrogenase}

Os tecidos musculares (branco e vermelho) foram homogeneizados em tampão fosfato de sódio $(10 \mathrm{mM})$ e $\mathrm{pH}$ 7,5 na proporção de 1:5 para proceder a extração das enzimas. Para tal, os tecidos foram triturados em homogeneizador tipo "potter" de alta velocidade durante dois minutos, na proporção de um grama de músculo para $5 \mathrm{~mL}$ de tampão de extração gelado $\left(4,0^{\circ} \mathrm{C}\right)$. Após homogeneização, centrifugaram-se as amostras a $800 \times g$ durante 10 minutos em centrifuga refrigerada. O sobrenadante, retirado cuidadosamente com uma pipeta Pasteur e transferido para tubos mantidos sobre gelo, foi utilizado para determinação da atividade máxima das enzimas antioxidantes.

A atividade da catalase (CAT) foi avaliada pelo consumo de peróxido de hidrogênio espectrofotometricamente a $240 \mathrm{~nm}$ e $25{ }^{\circ} \mathrm{C}$ por três minutos e foi expressa em $\mu$ mol de $\mathrm{H}_{2} \mathrm{O}_{2}$ consumido por minuto por miligrama de proteína. O meio de ensaio continha tampão fosfato de potássio $50 \mathrm{mM} \mathrm{pH} \mathrm{7,0} \mathrm{e} \mathrm{peróxido} \mathrm{de}$ hidrogênio 10 mM (BEERS; SIZER, 1952).

A atividade da glutationa redutase (GR) foi avaliada espectrofotometricamente através da oxidação do NADPH com a concomitante redução da glutationa oxidada a $340 \mathrm{~nm}$ e $25^{\circ} \mathrm{C}$ por três minutos. A atividade foi expressa em nmol de NADPH oxidado por minuto por miligrama de proteína. O meio de ensaio continha tampão fosfato de potássio $100 \mathrm{mM}$ pH 7,0, EDTA $1 \mathrm{mM}$; NADPH 0,1 mM e GSSG $1 \mathrm{mM}$ (CARLBERG; MANNERVIK, 1985). 
A atividade da lactato desidrogenase (LDH) foi avaliada espectrofotometricamente através da oxidação do NADH a $340 \mathrm{~nm}$ e $25^{\circ} \mathrm{C}$ por três minutos. A atividade foi expressa em $\mu$ mol de NADH oxidado por minuto por miligrama de proteína. O meio de ensaio continha tampão fosfato de sódio $20 \mathrm{mM}$ pH 7,4, ácido pirúvico 1 mM e NADH 0,1 mM (BERNT; BERGMEYER, 1974).

\subsubsection{Determinação dos níveis de oxidação lipídica}

Os produtos da oxidação lipídica foram mensurados por meio das substâncias reativas ao ácido tiobarbitúrico (TBARS). O tecido foi homogeneizado em tampão fosfato de sódio $10 \mathrm{mM} \mathrm{pH} \mathrm{7,4} \mathrm{contendo} \mathrm{BHT} \mathrm{0,2 \% ,} \mathrm{(na} \mathrm{proporção} \mathrm{de} 1 \mathrm{~g}$ de tecido / $5 \mathrm{ml}$ de tampão) e centrifugado a $3578 \times \mathrm{g}$ por 10 minutos. Os TBARS foram determinadas incubando-se uma alíquota do sobrenadante com o reagente contendo ácido tiobarbitúrico $0,38 \%$, ácido tricloroacético $15 \%$ e ácido clorídrico 0,76\%. Após incubação a $95{ }^{\circ} \mathrm{C}$ por 15 minutos, as amostras foram resfriadas em gelo por 10 minutos e centrifugadas a 7393 x g por 10 minutos. A absorbância do sobrenadante foi determinada a $535 \mathrm{~nm}$ em espectrofotômetro. TBARS foram determinados utilizando-se o coeficiente de extinção molar de $1,56 \times 10^{5} \mathrm{M}^{-1} . \mathrm{cm}^{-1}$. (BUEGE; AUST, 1978). 


\subsubsection{Avaliação da cor instrumental}

A cor instrumental foi determinada em triplicata, utilizando-se 10 filés de cada tratamento, com o emprego de um colorimetro portátil (Miniscan XE, Hunterlab), previamente calibrado com padrão branco e preto antes de cada análise, operando com fonte de luz D65, ângulo de observação de $10^{\circ}$ e abertura de célula de medida de $30 \mathrm{~mm}$. A cor foi expressa utilizando-se os padrões de cor do sistema CIELab "Comission Internationate de L'Eclairage": L* (luminosidade), a* (intensidade da cor vermelha-verde) e $b^{*}$ (intensidade da cor amarela-azul).

\subsubsection{Determinação de proteínas totais}

O conteúdo de proteínas das amostras foi determinado espectrofotometricamente pelo método descrito por Bradford (1976), usando soro albumina bovina para construção da curva padrão.

\subsection{Análise dos resultados}

Todos os dados foram submetidos à ANOVA, através do programa Minitab ${ }^{\circledR}$, comparando-se as médias por meio do teste Tukey $(p<0,05)$. 


\section{RESULTADOS E DISCUSSÃO}

\subsection{Etapa 1 - Efeito da suplementação com licopeno sobre a atrato- palatabilidade da ração}

A alimentação é o processo pelo qual um animal seleciona itens alimentares específicos dentre as fontes presentes no meio, sendo norteado pelos constituintes químicos do alimento e pela sua quimiosensibilidade (ADAMS et al., 1988). Independentemente dos órgãos sensoriais envolvidos na alimentação, o paladar é considerado o responsável pela seleção final, definindo a ingestão ou a rejeição de um alimento, ou até mesmo a quantidade a ser consumida (MEARNS, 1986).

No presente estudo, a inclusão de licopeno na ração comercial para juvenis de tilapia do Nilo não alterou a atrato-palatabilidade da ração avaliada por meio do registro das freqüências de visitas ao comedouro e quantidade de ração ingerida (Tabela 1).

Não foram observadas diferenças significativas em nenhum dos parâmetros de atrato-palatabilidade analisados, ao comparar os resultados obtidos dos animais dos grupos que receberam licopeno nas diferentes quantidades $(100,200,400$ ou $800 \mathrm{mg} / \mathrm{kg}$ de ração) veiculado em alginato de sódio e grupo controle que recebeu ração isenta de licopeno contendo apenas alginato de sódio. Estes resultados mostram que as respostas foram semelhantes para todas as concentrações de licopeno empregadas no presente estudo, não apresentando atrato-palatabilidade superior ou inferior à da ração controle. 
Johnston et. al. (1994) em seus estudos verificaram que não houve diferença na atrato-palatabilidade de rações coloridas (vermelho, verde e marrom) para truta arco-íris, Oncorhynchus mykiss, corroborando com os resultados apresentados no presente estudo uma vez que o licopeno conferiu uma coloração avermelhada à ração comercial.

Tabela 1 - Comportamento alimentar de juvenis de tilápia do Nilo alimentados com dietas contendo diferentes concentrações de licopeno (0 - controle, 100, 200, 400 e $800 \mathrm{mg} / \mathrm{kg}$ de ração).

\begin{tabular}{ccc}
\hline $\begin{array}{c}\text { Licopeno } \\
\text { (mg/kg de } \\
\text { ração) }\end{array}$ & $\begin{array}{c}\text { Visitas ao comedouro } \\
\text { (visita/minuto) }\end{array}$ & $\begin{array}{c}\text { Consumo de ração } \\
\text { ( }^{\circ} \text { de grânulos) }\end{array}$ \\
\hline 0 & $4,05 \pm 2,12^{a}$ & $7,47 \pm 3,71^{a}$ \\
100 & $2,76 \pm 2,11^{a}$ & $7,46 \pm 3,88^{a}$ \\
200 & $2,81 \pm 1,82^{a}$ & $7,70 \pm 3,72^{a}$ \\
400 & $3,17 \pm 2,25^{a}$ & $8,63 \pm 2,06^{a}$ \\
800 & $3,08 \pm 2,31^{a}$ & $8,36 \pm 2,87^{a}$
\end{tabular}

Resultados expressos como média e desvio padrão ( $n=5$ animais/tratamento). Para cada parâmetro avaliado letras iguais não apresentam diferença ao nível de significância de $5 \%$. Peso médio de cada grânulo $60 \pm 12 \mathrm{mg}$.

Adotou-se para os próximos experimentos, apresentados nesta tese, a concentração de 800 miligramas de licopeno por quilograma de ração veiculada em alginato de sódio para o grupo experimental e a ração isenta de licopeno, contendo apenas o veículo, para o grupo denominado controle. Sob esta condição, análise por espectrofotometria revelou 618,62 \pm 37,24 miligramas de licopeno por 
quilograma de ração, sem apresentar alteração significativa quanto ao tempo de armazenamento, sob refrigeração, por 7 e 15 dias. Resultado expresso como média e desvio padrão de ensaios realizados em triplicata.

\subsection{Etapa 2 - Efeito do licopeno na promoção do bem-estar de juvenis de tilápia do Nilo, (Oreochromis niloticus).}

\subsubsection{Efeito do licopeno sobre parâmetros zootécnicos e bioquímicos de juvenis de tilápia do Nilo não submetidos a estresse}

Nos últimos anos, com a necessidade de garantir o bem-estar animal associado à produtividade e qualidade dos produtos finais, estudos em piscicultura vêm adotando técnicas alternativas como a suplementação animal.

A incorporação de antioxidante como o ß-caroteno na dieta de trutas demonstrou aumentar a resposta imune do animal (AMAR et al., 2000), e as vitaminas $\mathrm{C}$ e $\mathrm{E}$ foram consideradas moderadoras de estresse em peixes, como dourada, robalo, turbot, atum (MERCHIE et al., 1997; MONTERO et al., 2001, 2003; ORTUÑO et al., 2003; AL-BANDAK, et.al., 2009). Recentes estudos com truta arcoíris mostraram que a suplementação com antioxidantes (vitamina E e C) reduziu o estresse oxidativo no tecido do peixe, além de promover o bem-estar animal (TRENZADO et al., 2009). 
No presente estudo observou-se que a inclusão de licopeno à dieta de tilápia do Nilo por 60 dias, não alterou nenhum dos parâmetros zootécnicos avaliados pelo ganho de peso, conversão alimentar, fator de condição, taxa de crescimento específico e consumo (Tabela 2). Estes resultados são positivos, pois demonstram que o licopeno pode ser incorporado na ração sem qualquer prejuízo ao desempenho das tilápias.

Com relação ao crescimento, a presença de estressores gera prejuízos na produção; e a redução do potencial de crescimento de peixes sob ação de agente estressor está ligada ao aumento do gasto energético na busca da homeostase (BARTON e IWAMA, 19991). O consumo também pode ser afetado, influenciando os índices de conversão alimentar. Braga (1986) em seus estudos afirma que o estado fisiológico de um peixe é condicionado pela interação de fatores bióticos e abióticos cujas variações podem ser estimadas por meio do fator de condição. Assim este parâmetro é considerado um indicador de bem-estar do peixe no ambiente em que se encontra. 
Tabela 2 - Efeito da suplementação com licopeno sobre o desempenho de juvenis de tilápia do Nilo (Oreochromis niloticus) avaliado no grupo controle e no grupo suplementado por 60 dias com licopeno (800 mg/kg de ração).

Parâmetros

GP

CA

FC

TCE

\section{Controle}

$$
20,58 \pm 7,61^{a}
$$$$
1,47 \pm 0,32^{a}
$$

$3,28 \pm 0,21^{a}$

$$
0,36 \pm 0,11^{a}
$$

$23,90 \pm 8,37^{a}$

\section{Licopeno}

$10,65 \pm 5,85^{a}$

$2,04 \pm 0,91^{a}$

$3,13 \pm 0,55^{a}$

$0,30 \pm 0,11^{a}$

CONSUMO

$\mathrm{GP}=$ ganho de peso $(\mathrm{g}), \mathrm{CA}=$ conversão alimentar, $\mathrm{FC}=$ fator de condição e TCE=taxa de crescimento específico (\%). Resultados expressos como média e desvio padrão ( $n=10$ animais/tratamento). Para cada parâmetro avaliado letras iguais não apresentam diferença ao nível de significância de 5\%.

Dentre os agentes potencialmente estressores para tilápia estão os parâmetros de qualidade da água. Mas, no presente estudo estes fatores foram aferidos no decorrer do experimento.

A tilápia, embora seja adaptada ao clima subtropical, não deve ser mantida em temperaturas inferiores a $15^{\circ} \mathrm{C}$ ou superiores a $35^{\circ} \mathrm{C}$ (KUBITZA, 2000). No presente estudo a temperatura foi mantida dentro desta faixa confortável $(27,60 \pm$ $0,23{ }^{\circ} \mathrm{C}$ ), não diferindo entre os tratamentos. Outros parâmetros que afetam o bemestar dos peixes são estão relacionados ao pH e concentrações de amônia, nitrito e oxigênio dissolvido na água. No presente estudo, todos estes fatores foram também mantidos dentro das faixas aceitáveis para tilápia (KUBITZA, 2000), ou seja, pH em $7,16 \pm 0,16$, amônia e nitrito não ultrapassaram $0,25 \mathrm{mg} / \mathrm{L}$ e oxigênio dissolvido em 
$6,08 \pm 0,07 \mathrm{mg} / \mathrm{L}$. A manutenção de todos estes parâmetros dentro de faixas préestabelecidas garante o estar-animal. Além do mais, nos sistemas aquáticos, mudanças na concentração de oxigênio e na temperatura são variáveis ambientais que podem influenciar no estresse oxidativo (PARIHAR et. al., 1997).

Com relação à qualidade do filé das tilápias suplementadas com licopeno observou que não houve alteração nos níveis da peroxidação lipídica quando comparado ao controle (Figura 3).

A peroxidação lipídica avaliada por meio da concentração de substâncias reativas ao ácido tiobarbitúrico (TBARS) em filé dos peixes suplementados e controles foi, respectivamente, $3,90 \pm 0,90 \mathrm{nmol} / \mathrm{g}$ de tecido úmido e 4,28 \pm 0,41 $\mathrm{nmol} / \mathrm{g}$ de tecido úmido.

A suplementação com licopeno não inibiu a peroxidação dos lipídeos no filé de tilápia, armazenado sob $-18^{\circ} \mathrm{C}$, ainda fresco. Estudos mostram que antioxidantes incorporados à ração de peixes aumentam a vida de prateleira dos produtos da carne e derivados. Resultados positivos com o uso de vitamina E como antioxidante, foram verificados para truta arco-íris (FRIGG et . al., 1990), turbot (STEPHAN et. al., 1995), salmão (ONIBI et. al., 1996), halibut do Atlântico (RUFF et. al., 2002), black sea bream (PENG et. al., 2009) entre outros. Entretanto, no presente estudo não foi avaliada a vida de prateleira do filé de tilápia suplementada com licopeno. 


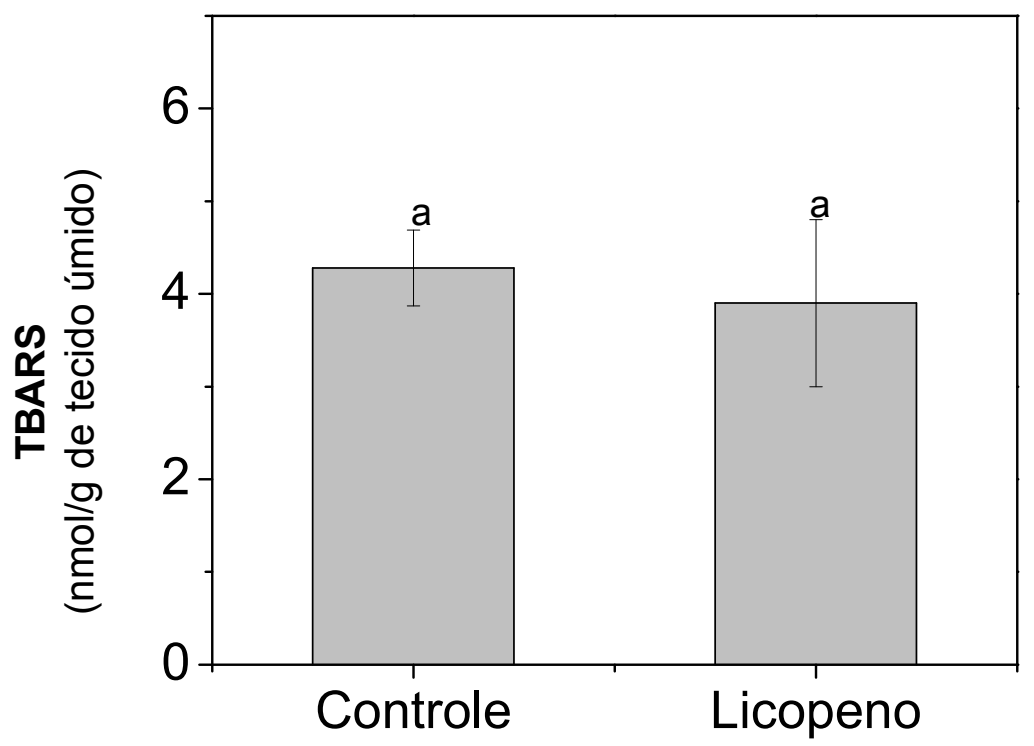

Figura 3 - Efeito da suplementação de juvenis de tilápia do Nilo (Oreochromis niloticus) com licopeno via ração sobre a concentração de substâncias reativas ao ácido tiobarbitúrico (TBARS) avaliado em filé (músculo branco) dos animais do grupo controle e do grupo submetido suplementado por 60 dias com licopeno (800 mg/kg de ração). Os resultados estão expressos como média e desvio padrão ( $n=10$ animais/tratamento). Letras iguais não apresentam diferença ao nível de significância de 5\%.

Carotenóides como a astaxantina é incluída na dieta como realçador da cor em trutas e salmões, propriedade desejável para o mercado consumidor (BOWEN et.al., 2002; BEJERKENG, et.al., 1999). Porém, para muitas espécies de peixes, como a tilápia do Nilo, não é desejável a alteração da cor caracteristicamente clara do filé.

De acordo com os resultados apresentados na Tabela 3 observou-se que a administração de licopeno não alterou a cor do filé de tilápia avaliado pela luminosidade, coeficiente da coloração amarela e vermelha; sugerindo que o 
licopeno, sob as condições do estudo, pode ser incorporado à dieta de tilápia do Nilo sem prejuízos da cor instrumental do filé.

Tabela 3 - Efeito da suplementação com licopeno sobre a cor do filé (músculo branco) determinada pela luminosidade $(L)$, coeficiente de coloração vermelha $(a)$ e coeficiente de coloração amarela (b) em juvenis de tilápia do Nilo (Oreochromis niloticus)

\begin{tabular}{ccc}
\hline Parâmetros & Controle & Licopeno \\
\hline $\mathrm{L}$ & $55,16 \pm 2,23^{\mathrm{a}}$ & $54,88 \pm 1,65^{a}$ \\
$\mathrm{a}$ & $2,31 \pm 0,98^{\mathrm{a}}$ & $2,41 \pm 0,92^{\mathrm{a}}$ \\
$\mathrm{b}$ & $9,74 \pm 0,95^{\mathrm{a}}$ & $9,95 \pm 0,83^{\mathrm{a}}$
\end{tabular}

Resultados expressos como média e desvio padrão ( $\mathrm{n}=10$ animais/tratamento). Letras iguais não apresentam diferença ao nível de significância de $5 \%$.

Uma característica importante refletida pela inclusão de licopeno na ração de tilápias do Nilo surgiu nos resultados da atividade de catalase no filé (Figura 2). Observou-se redução na atividade de catalase em 34\% no filé (músculo branco) dos peixes suplementados com o antioxidante em relação aos animais do grupo controle (suplementado: 1,09 $\pm 0,24 \mu \mathrm{mol} / \mathrm{min} / \mathrm{mg}$ de proteína e controle:1,77 \pm 0,35 $\mu \mathrm{mol} / \mathrm{min} / \mathrm{mg}$ de proteína) (Figura 4).

A redução de atividade das enzimas antioxidantes pode ser discutida sob dois aspectos, um que caracteriza a condição de estresse oxidativo intenso com prejuízos de integridade e perda da funcionalidade das enzimas e outro, que caracteriza um estado favorável de manutenção do estado redox da célula (HALLIWELL e GUTTERIDGE, 2007). O paradigma do estado redox celular está em 
um conjunto de características do material biológico. No presente estudo, o nível de peroxidação lipídica do file não foi alterado, refletindo uma condição de equilíbrio entre as espécies oxidantes e compostos antioxidantes presentes no tecido. Assim, a redução de atividade de catalase, como a que foi encontrada neste trabalho, sugere que o licopeno atuou como antioxidante no file de tilápia contra as espécies oxidantes geradas pelo metabolismo celular, diminuindo a necessidade da atuação da catalase.

Estudos mostram que a expressão gênica da enzima catalase aumenta mediante estresse oxidativo (HALLIWELL e GUTTERIDGE, 2007) e diminui na presença de antioxidantes exógenos (MOURÃO et. al., 2009). Neste último trabalho os autores evidenciaram que animais suplementados com antioxidante natural reduziram a expressão gênica da catalase com a conseqüente redução de atividade enzimática; resultados similares também foram observados na expressão gênica e atividade da enzima glutationa redutase.

No presente estudo, a atividade da enzima glutationa redutase não foi alterada pela administração de licopeno (Figura 4) avaliada no filé de tilápias do Nilo do grupo controle e experimental $(1,80 \pm 0,21 \mathrm{nmol} / \mathrm{min} / \mathrm{mg}$ de proteína e 1,71 $\pm 0,23$ $\mathrm{nmol} / \mathrm{min} / \mathrm{mg}$ de proteína, respectivamente). Estes resultados sugerem que a enzima glutationa redutase foi pouco sensível aos efeitos da inclusão de licopeno na ração de tilápias.

Na Figura 4 encontram-se, também, os resultados de atividade de catalase e glutationa redutase para o músculo vermelho de tilápias do Nilo do grupo controle e suplementado com licopeno sem diferença significativa entre eles. 
Os valores de atividade da catalase para o músculo vermelho dos peixes do grupo controle e suplementado foram, respectivamente, 3,02 $\pm 0,29 \mu \mathrm{mol} / \mathrm{min} / \mathrm{mg}$ de proteína e de $2,71 \pm 0,47 \mu \mathrm{mol} / \mathrm{min} / \mathrm{mg}$ de proteína. Os valores registrados para glutationa redutase foram de $3,21 \pm 0,58 \mathrm{nmol} / \mathrm{min} / \mathrm{mg}$ de proteína e de 2,65 $\pm 0,34$ $\mathrm{nmol} / \mathrm{min} / \mathrm{mg}$ de proteína respectivamente para este músculo.

As características do músculo vermelho conferem a este tecido a predominância de metabolismo aeróbio, enquanto que o tecido branco, como o file de tilápia, a geração de energia é por via anaeróbia. Quanto mais ativado for o metabolismo aeróbio maiores são os mecanismos antioxidantes intrínsecos da célula em resposta as ERO geradas (HALLIWELL, 1994).

Para tilápia do Nilo os valores de atividade de catalase e glutationa redutase no músculo vermelho são superiores em $71 \%$ e $78 \%$ que as respectivas enzimas no músculo branco, como apresentado na Figura 2 para o grupo controle $(p<0,05)$. Estes resultados são similares aos encontrados por Almeida et al. (2002) em seus estudos com tilápia do Nilo. A atuação do licopeno como antioxidante no músculo vermelho de tilápia para ambas as enzimas antioxidantes não foi expressiva, possivelmente, em decorrência da alta atividade de enzimas antioxidantes neste tecido em virtude do metabolismo aeróbio. 

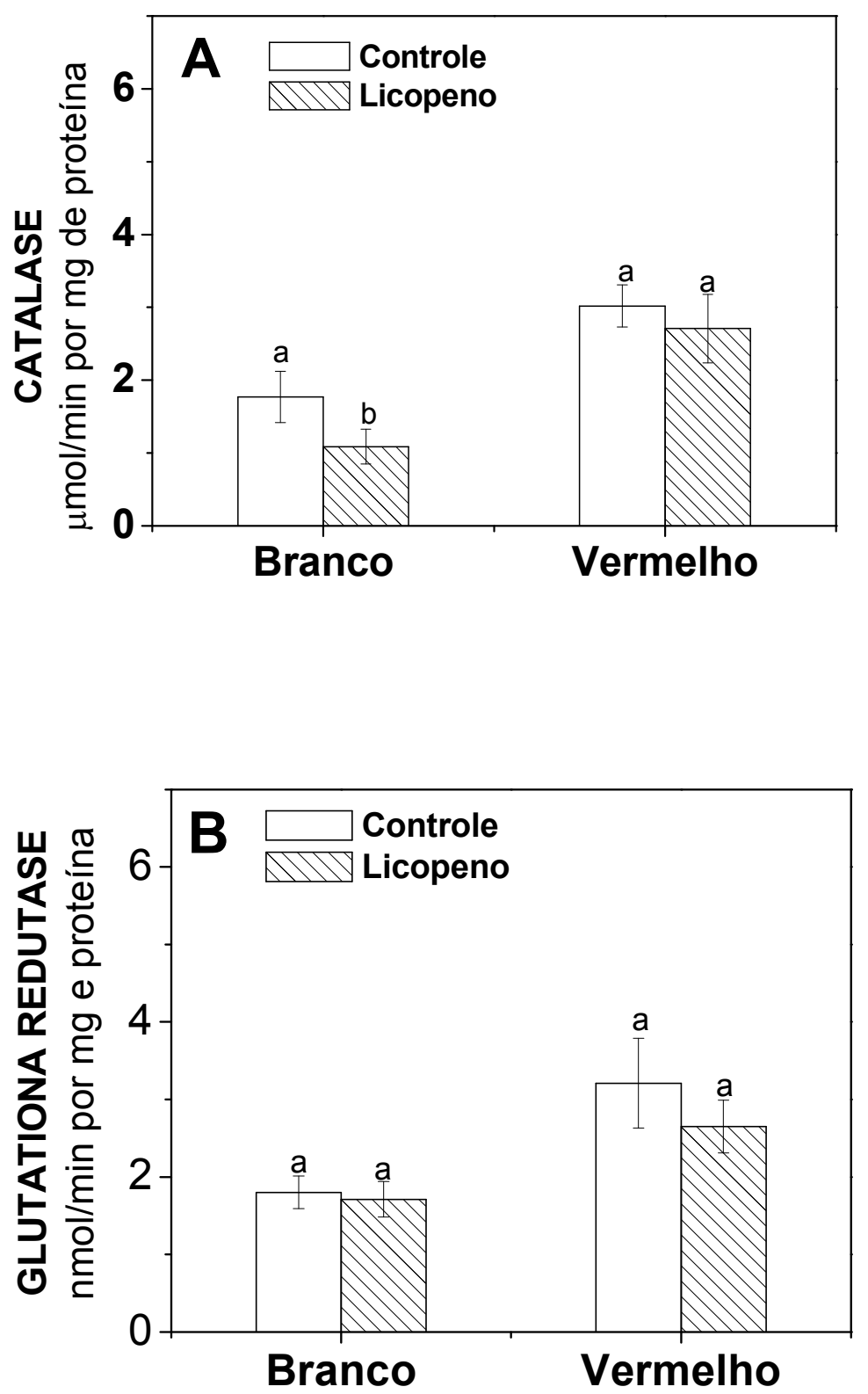

Figura 4 - Efeito da adição de licopeno (800 mg/kg de ração) durante 60 dias sobre a atividade de enzimas antioxidantes presentes em músculo branco e vermelho de juvenis de tilápias do Nilo (Oreochromis niloticus). (A) Atividade da catalase e (B) Atividade da glutationa redutase. Resultados expressos como média e desvio padrão ( $n=10$ animais/tratamento). Para cada grupo de músculo, letras diferentes indicam diferença ao nível de significância de 5\%. 
Conforme apresentado na Figura 5, a atividade da lactato desidrogenase do filé e músculo vermelho também não apresentou alteração em função da suplementação da dieta dos peixes com licopeno. Estes resultados demonstram que a incorporação de licopeno na dieta de tilápia do Nilo não alterou o metabolismo anaeróbio nos tecidos estudados.

Para a musculatura branca registraram-se valores de atividade de lactato desidrogenase para o grupo controle e o experimental de $10,90 \pm 1,21 \mu \mathrm{mol} / \mathrm{min} / \mathrm{mg}$ de proteína e 9,60 $\pm 1,51 \mu \mathrm{mol} / \mathrm{min} / \mathrm{mg}$ de proteína, respectivamente. Para a musculatura vermelha, nos peixes do grupo tratado com licopeno registraram-se valores de $9,10 \pm 1,50 \mu \mathrm{mol} / \mathrm{min} / \mathrm{mg}$ de proteína e no grupo controle 11,37 $\pm 1,0$ $\mu \mathrm{mol} / \mathrm{min} / \mathrm{mg}$ de proteína para este músculo. 


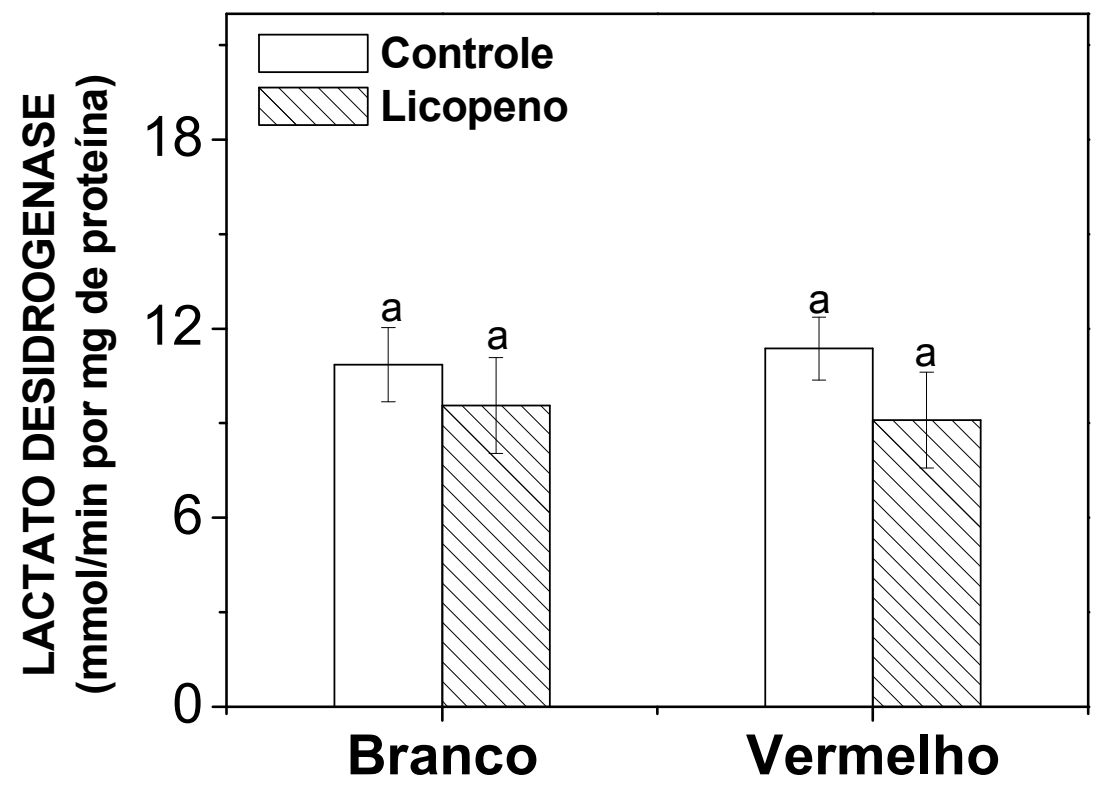

Figura 5 - Efeito da adição de licopeno (800 mg/kg de ração) durante 60 dias sobre a atividade da lactato desidrogenase presente em músculo branco e vermelho de juvenis de tilápias do Nilo (Oreochromis niloticus). Resultados expressos como média e desvio padrão ( $n=10$ animais/tratamento). Para cada grupo de músculo, letras iguais não apresentam diferença ao nível de significância de 5\%.

Os antioxidantes apresentam características importantes em aquicultura tanto para aumentar a produtividade quanto para melhorar a qualidade da carne. O uso de antioxidantes naturais como o licopeno tem despertado interesse para nutrição animal e no presente estudo evidenciou a possibilidade de inclusão deste antioxidante na ração de peixes, até então, empregado somente na dieta de outros animais. 


\subsubsection{Efeitos do estresse por contenção sobre parâmetros bioquímicos de juvenis de tilápia do Nilo (Oreochromis niloticus)}

O estresse pode ser considerado como um conjunto de respostas não específicas do organismo a situações que ameaçam desequilibrar a sua homeostase (BARTON, 2002). Os peixes sob criação intensiva estão susceptíveis a vários agentes estressores destacando o manejo e, principalmente, a qualidade da água (URBINATI e CARNEIRO, 2004). Nos últimos anos varias metodologias foram desenvolvidas para minimizar o estresse e seus potenciais efeitos nocivos sobre os peixes em cultivo, principalmente sobre o bem-estar, qualidade e produtividade. Neste contexto, a prática de monitoramento constante dos animais e do ambiente aquático como a natureza química da água tem demonstrado eficiência na redução do estresse de peixes (CONTE, 2004).

Uma ferramenta amplamente empregada como indicador de estresse em tilápia do Nilo é a analise das características físicas do animal como escurecimento corporal (O'CONNOR et al, 1999, VOLPATO 2003). No presente estudo, verificou-se que os animais submetidos ao agente estressor apresentaram mudanças no padrão de coloração, de claro para escuro. A Figura 6 apresenta fotografias registradas de animal antes e após o desafio de contenção. 


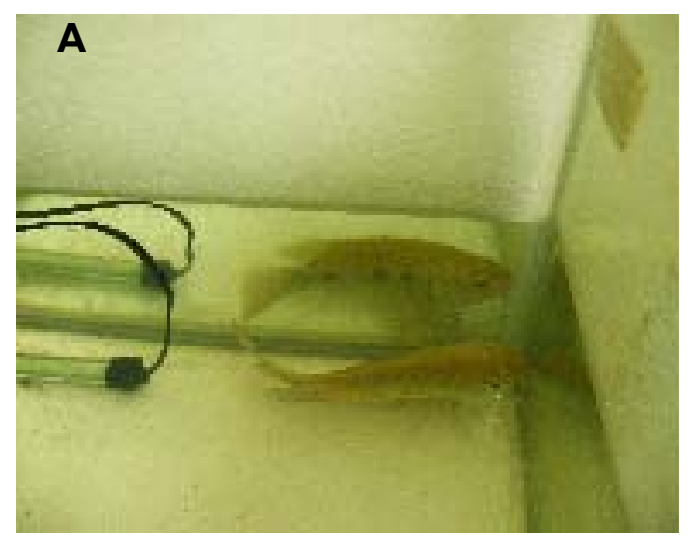

Antes

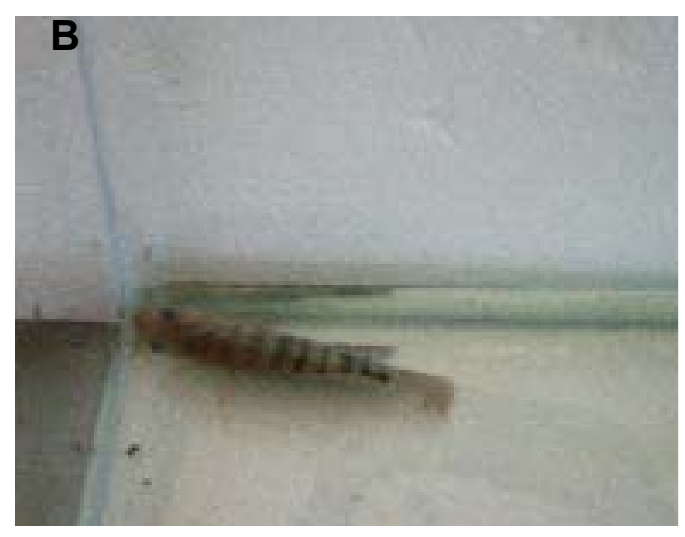

\section{Depois}

Figura 6.- Imagem de tilápia do Nilo antes (A) e após estresse de contenção por redução do nível de água $(B)$.

Corroborando como os resultados das características físicas do animal estão os níveis de cortisol da tilápia do Nilo, demonstrando condições adequadas de manutenção e manejo durante o período experimental e, ainda, o desafio de contenção imposto a tilápia aumentou o nível de cortisol.

Na Figura 7 encontram-se os resultados referentes às concentrações basais de cortisol no plasma dos peixes do grupo controle e do grupo destinado ao estresse de contenção. Esta figura apresenta, também, o efeito do estresse de contenção (90 minutos) sobre a concentração de cortisol.

Os valores encontrados para concentração basal de cortisol plasmático nos peixes do grupo controle foi de 14,12 $\pm 2,50 \mathrm{ng} / \mathrm{mL}$ e os registrados após 90 minutos foi de $12,51 \pm 2,43 \mathrm{ng} / \mathrm{mL}$, sem diferença significativa entre eles, sendo esses o final do experimento, valores similares aos encontrados na literatura para tilapia do Nilo (VOLPATO e BARRETO, 2001).

Estabelecer níveis basais de cortisol para tilápias depende de diferentes fatores como estação do ano, horário da colheita de sangue para análise, etc. 
Porém, estudos sugerem que concentrações plasmáticas de cortisol na faixa de 5 a 50 ng/mL para tilápias do Nilo são características do bem-estar animal (VOLPATO e BARRETO, 2001). De acordo com o exposto, conclui-se que as condições estabelecidas para os animais, no presente estudo, foram favoráveis ao bem-estar animal.

Entretanto, o desafio de contenção provocou um aumento de $53 \%$ do nível de cortisol plasmático dos peixes (valores iniciais: $16,23 \pm 2,81 \mathrm{ng} / \mathrm{mL}$; valores finais: $24,72 \pm 4,30 \mathrm{ng} / \mathrm{mL})$, sugerindo que o protocolo empregado para indução do estresse (contenção) foi adequado e eficiente.

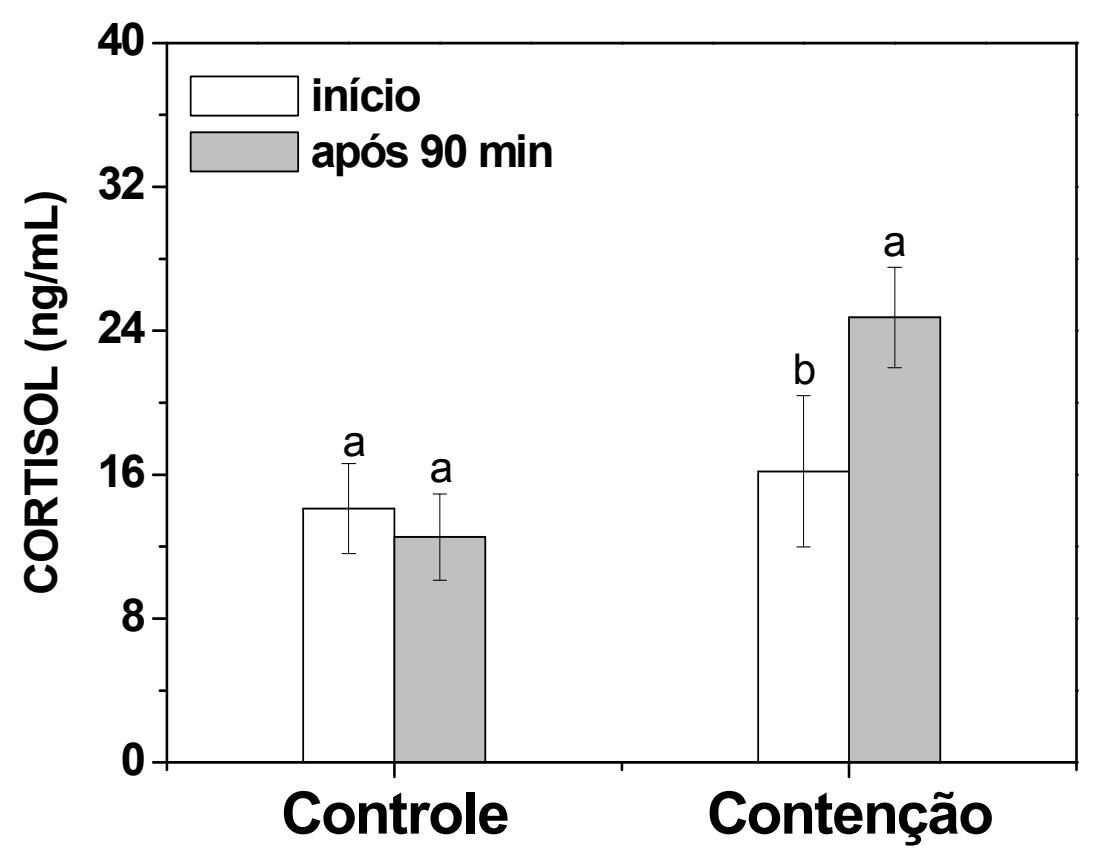

Figura 7 - Concentração plasmática de cortisol em juvenis de tilápia do Nilo (Oreochromis niloticus) submetidos a estresse de contenção durante 90 minutos. Resultados expressos como média e desvio padrão ( $n=10$ animais/tratamento). Para cada grupo avaliado, letras diferentes indicam diferença ao nível de significância de 5\%. 
Para os peixes os agentes estressores podem ser de natureza física como transporte, confinamento e manuseio e, ainda de natureza química como poluentes teor de oxigênio e acidez da água. No presente estudo estas características foram asseguradas ao longo do período experimental, refletido pela cor clara do animal e também pelo nível de cortisol dos animais do grupo controle. Entretanto, em resposta ao agente estressor, estabelecido pela restrição do espaço, os peixes aumentaram a concentração de cortisol plasmático em acordo com outros estudos para tilápias do Nilo submetidas a estresse por meio de confinamento em espaço restrito dentro do próprio aquário (BARRETO et. al., 2009, VOLPATO e BARRETO, 2001, BARRETO e VOLPATO, 2004).

Desafio por restrição de espaço, similar ao empregado no presente estudo, foi conduzido por Guerriero et.al., (2002) para robalo do Atlântico, Dicentrarchus labrax, demonstrando uma relação direta entre a condição imposta ao animal e o aumento no estresse. De acordo com exposto sugere-se um novo modelo de agente estressor para tilápia do Nilo, caracterizado pela redução do nível de água até expor a nadadeira dorsal do animal decorrendo no aumento da concentração plasmática de cortisol.

Inúmeras alterações bioquímicas e fisiológicas estão associadas ao aumento do fluxo de oxiradicais resultantes do estresse oxidativo. Assim, Oost et. al., (2003) relata que algumas destas perturbações bioquímicas podem ser configuradas como biomarcadores, entre eles valores de peroxidação lipídica obtidos através do teste de TBARS, que quantifica o malonaldeído (MDA), um dos principais produtos de decomposição dos hidroperóxidos de ácidos graxos poliinsaturados, formados durante o processo oxidativo (OSAWA, et. al., 2005). A peroxidação lipídica é descrita como responsável pela perda das funções da célula sob condições de 
estresse oxidativo (STOREY, 1996). Em organismos aquáticos como caranguejos e peixes (WIHELM-FILHO et. al., 2001; SARGENT et al., 2002; PINHO et al., 2005; SMITH et al., 2007; OLIVEIRA et al., 2008; PENG et al., 2009) os níveis de TBARS são usados para evidenciar estresse oxidativo.

No presente estudo, o desafio por contenção aumentou em $28 \%$ os níveis de peroxidação lipídica no filé da tilápia, avaliados por meio de TBARS (Figura 8). Estes resultados sugerem que o agente estressor provocou um aumento das espécies reativas de oxigênio que culminou com a indução de um efeito indesejado no filé, conhecido como peroxidação lipídica.

Foram registrados os respectivos valores de TBARS nas amostras de filé de tilápias do grupo controle e submetido ao desafio de contenção respectivamente: 4,28 \pm 0,41 $\mathrm{nmol} / \mathrm{g}$ de tecido úmido e $5,48 \pm 0,47 \mathrm{nmol} / \mathrm{g}$ de tecido úmido.

A peroxidação lipídica é particularmente importante para os animais aquáticos, que normalmente possuem níveis altos de ácidos graxos insaturados, comparados aos demais animais (HUANG et. al., 2003). Considerando que durante a ação das ERO ocorre peroxidação de ácidos graxos insaturados, os resultados apresentados mostram claramente que o estresse de contenção decorreu em estresse oxidativo avaliado pelo aumento significativo dos níveis de TBARS. Resultados semelhantes, porém sob outros agentes estressores, foram encontrados em estudos com tilápias expostas a cianobactérias (PRIETO, et. al., 2007; ATENCIO, et. al., 2009), tilápia expostas a efluentes de suínos (LIMA et. al., 2006) e também com caracídeo Brycon cephalus exposto a organofosforado (MONTEIRO et. al., 2006). 
A peroxidação lipídica em alimento de origem animal decorre de vários fatores como o contato com o oxigênio, altas temperatura de acondicionamento, exposição à radiação ionizante e, principalmente, o perfil lipídico da matéria prima (OLIVO, 2006). Sendo uma das principais causa da rancidez de alimento, a peroxidação lipídica altera o sabor, reduz o valor nutricional e gera produtos tóxicos como o malondialdeído nos alimentos (SUMMO et al., 2006). De acordo com o exposto, a qualidade do filé de tilápia do Nilo pode ser afetada pela exposição do animal a situações de estresse avaliadas pelas TBARS.

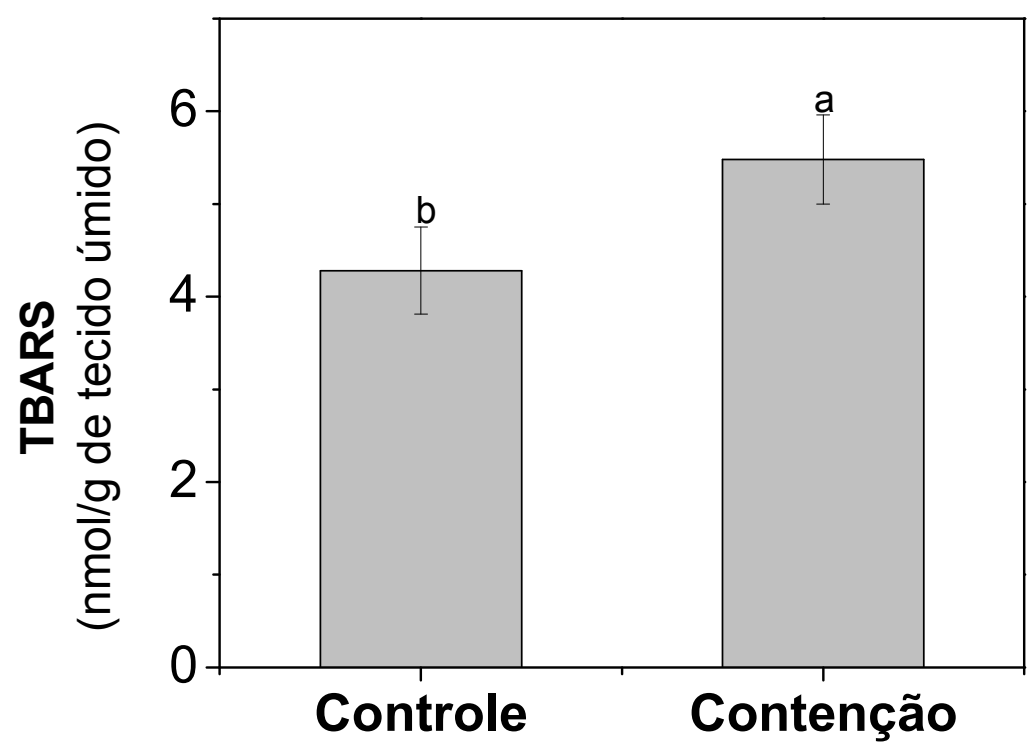

Figura 8 - Efeito da contenção (90 minutos) de juvenis de tilápia do Nilo (Oreochromis niloticus) sobre a concentração de substancias reativas ao ácido tiobarbitúrico (TBARS) na musculatura branca. Resultados expressos como média e desvio padrão $(n=10$ animais/tratamento). Para cada tratamento avaliado, letras diferentes indicam diferença ao nível de significância de 5\%. 
Entretanto, o desafio estabelecido pela contenção de 90 minutos não alterou os parâmetros de cor instrumental do filé de tilápia, determinados pela luminosidade, coeficiente de coloração amarela e coeficiente de coloração vermelha, em relação aos respectivos parâmetros do grupo controle (Tabela 4).

Tabela 4 - Efeito da contenção (90 minutos) de juvenis de tilápia do Nilo (Oreochromis niloticus) sobre a cor do filé (músculo branco) determinada pela luminosidade (L), coeficiente de coloração vermelha (a) e coeficiente de coloração amarela (b).

\begin{tabular}{ccc}
\hline Parâmetros & Controle & Contenção \\
\hline L & $55,16 \pm 2,23^{a}$ & $54,24 \pm 1,63^{a}$ \\
a & $2,31 \pm 0,98^{a}$ & $2,49 \pm 0,62^{a}$ \\
b & $9,74 \pm 0,95^{a}$ & $9,81 \pm 0,70^{a}$
\end{tabular}

Resultados expressos como média e desvio padrão ( $n=10$ animais/tratamento). Letras iguais não apresentam diferença ao nível de significância de $5 \%$.

Potenciais biomarcadores podem derivar das respostas adaptativas à oxidação, como a atividade das enzimas antioxidantes, ou a danos oxidativos (WINSTON e DI GIULIO, 1991 e WHILHELM-FILHO, 1996). A quantificação das mudanças nos níveis da atividade enzimática em diferentes organismos aquáticos, incluindo os peixes, é muito utilizada como biomarcadores do estresse oxidativo (WHILHELM-FILHO, 1996; AHMAD et. al., 2000; LIVINGSTONE, 2001; ORUC et. al., 2004; FERREIRA, 2005). 
Assim como no presente estudo, o estresse de oxidativo tem sido sugerido também para se avaliar o estresse de contenção (VOLPATO e BARRETO, 2001, GUERRIERO, 2002). Porém, na maioria dos estudos, a indução ao estresse oxidativo em peixes tem sido feita mediante a exposição dos animais a poluentes, toxinas, metais pesados e pesticidas (ALMEIDA, 2001, 2002; BASHA e RANI, 2003; MONTEIRO et. al., 2006; VEGA-LOPEZ et. al., 2007; FIGUEIREDO-FERNANDES, 2006; PEIXOTO et. al., 2006; ATENCIO et. al., 2009).

Considerando que os sistemas enzimáticos e não enzimáticos são essências para a manutenção do estado redox e constituintes importantes para a defesa dos peixes contra o estresse oxidativo, no presente estudo, avaliou-se a atividade das enzimas antioxidantes. A condição de estresse promoveu o aumento da atividade das enzimas catalase e glutationa redutase no filé e no músculo vermelho de tilápia do Nilo.

De acordo com os resultados apresentados na Figura 9, a atividade da enzima catalase no filé aumentou em $31 \%$ nos peixes submetidos ao estresse de contenção $(2,32 \pm 0,21 \mu \mathrm{mol} / \mathrm{min} / \mathrm{mg}$ de proteína), comparativamente ao grupo controle $(1,77 \pm 0,35 \mu \mathrm{mol} / \mathrm{min} / \mathrm{mg}$ de proteína). Observou-se que a contenção aumentou $47 \%$ a atividade da catalase no músculo vermelho $(4,45 \pm 0,48$ $\mu \mathrm{mol} / \mathrm{min} / \mathrm{mg}$ de proteína), comparativamente ao controle $(3,02 \pm 0,29 \mu \mathrm{mol} / \mathrm{min} / \mathrm{mg}$ de proteína). Já a atividade da glutationa redutase nos peixes submetidos à contenção apresentou aumento de $32 \%$ para o filé $(2,37 \pm 0,23 \mathrm{nmol} / \mathrm{min} / \mathrm{mg}$ de proteína), comparativamente ao grupo controle $(1,80 \pm 0,21 \mathrm{nmol} / \mathrm{min} / \mathrm{mg}$ de proteína). Em relação à musculatura vermelha, o aumento foi de $46 \%(4,70 \pm 0,69$ $\mathrm{nmol} / \mathrm{min} / \mathrm{mg}$ de proteína), comparativamente ao controle $(3,21 \pm 0,58 \mathrm{nmol} / \mathrm{min} / \mathrm{mg}$ 
de proteína). Estes resultados sugerem que a condição de contenção foi efetiva na geração de estresse oxidativo nos peixes.
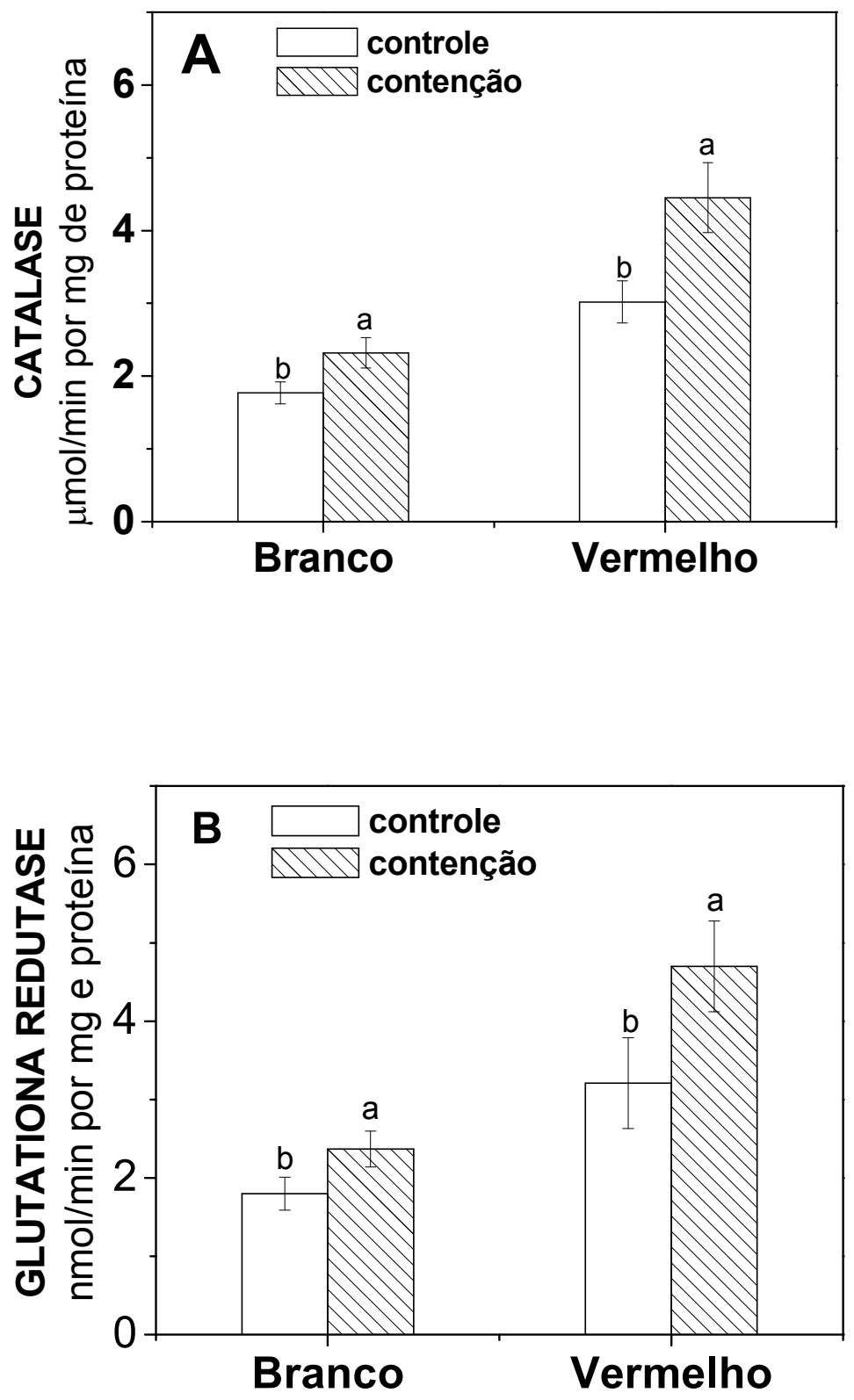

Figura 9 - Efeito da contenção (90 minutos) sobre a atividade de enzimas antioxidantes presentes nos músculos brancos e vermelhos de juvenis de tilápias do Nilo (Oreochromis niloticus). (A) Atividade da catalase e (B) Atividade da glutationa redutase. Resultados expressos como média e desvio padrão ( $n=10$ peixes/tratamento). Para cada grupo de músculo, letras diferentes indicam diferença ao nível de significância de 5\%. 
Segundo Pandey et. al, (2003) a catalase é considerada a principal enzima antioxidante, já que constitui a primeira linha de defesa frente as $\mathrm{ERO}$, convertendo o peróxido de hidrogênio em oxigênio e água (ATLI e CANLI, 2007). A atividade de catalase é utilizada como um biomarcador de estresse oxidativo em vários órgãos e tecidos de animais (OOST et. al., 2003 e OGUNJI et. al., 2007).

Os valores da atividade da catalase, no presente estudo, foram maiores quando as tilápias foram submetidas ao estresse de contenção, dados concordantes com Monteirol et. al. (2006) para o caracídeo Brycon cephalus exposto a inseticidas organofosforados. Segundo estes autores o aumento na atividade enzimática da catalase reflete a neutralização das ERO produzidas em resposta ao estresse. Nesta mesma linha, Alves et. al., (2002) avaliaram as respostas adaptativas de moluscos pelo aumento na atividade de enzimas antioxidantes.

A enzima glutationa redutase também é considerada biomarcadora do estresse oxidativo, além de ser a encarregada de manter a relação GSH/GSSG em condições de estresse (WINSTON e DI GIULIO, 1991). Estudos com tilápia mostraram que a atividade desta enzima aumentou significativamente mediante exposição do animal a cianobactérias (ATENCIO et. al., 2009; Jos et. al.2005), ao cádmio (ALMEIDA, 2002), ao paraquat (FIGUEREIDO-FERNANDES et. al., 2006) e a outros pesticidas (Peixoto et. al., 2006). Resultados semelhantes foram encontrados pela exposição de trutas arco-íris ao paraquat (AKERMAN et. al., 2003)

O aumento de atividade das enzimas antioxidantes catalase e glutationa redutase decorrente do estresse de contenção reflete o aumento do metabolismo aeróbio durante este desafio para juvenis de tilápia do Nilo. Por outro lado, o estresse de contenção induziu também o metabolismo anaeróbio avaliado pelo 
aumento da atividade da lactato desidrogenase, principalmente na musculatura vermelha dos peixes.

Os resultados referentes à ação da contenção de tilápias do Nilo sob a atividade da LDH no filé e no músculo vermelho encontram-se na Figura 10. Observou-se um aumento de $28 \%$ na atividade da LDH no músculo branco $(14,00 \pm$ $1,37 \mu \mathrm{mol} / \mathrm{min} / \mathrm{mg}$ de proteína) em relação ao controle $(10,90 \pm 1,21 \mu \mathrm{mol} / \mathrm{min} / \mathrm{mg}$ de proteína), nos peixes submetidos ao estresse de contenção. A atividade dessa enzima na musculatura vermelha foi de $11,37 \pm 1,00 \mu \mathrm{mol} / \mathrm{min} / \mathrm{mg}$ de proteína para o grupo controle e de $16,31 \pm 1,52 \mu \mathrm{mol} / \mathrm{min} / \mathrm{mg}$ de proteína no grupo submetido à contenção, ou seja, um aumento de $43 \%$ de atividade. 


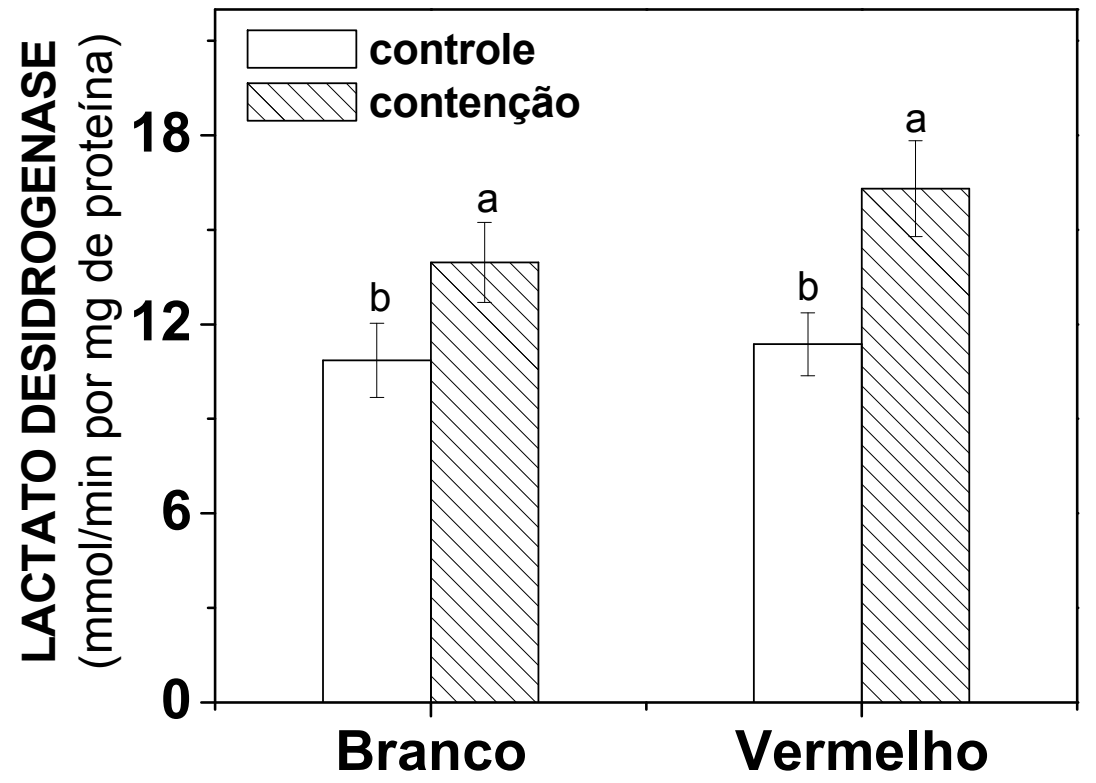

Figura 10 - Efeito da contenção (90 minutos) sobre atividade de lactato desidrogenase avaliada no músculo branco e vermelho de juvenis de tilápia do Nilo (Oreochromis niloticus). Resultados expressos como média e desvio padrão ( $n=10$ peixes/tratamento. Para cada grupo de músculo, letras diferentes indicam diferença ao nível de significância de 5\%.

O aumento de atividade da LDH, como o evidenciado no presente estudo, reflete uma resposta secundária da tilápia ao agente estressor. Esta enzima é responsável pela formação de acido láctico durante o metabolismo anaeróbio. Estes resultados estão em acordo com o estudo realizado por Wendelaar (1997), em que foi observado o acúmulo de ácido lático na musculatura e sangue dos peixes (hiperlactemia) em resposta a atividade extrema como uma natação vigorosa. Outros autores demonstraram que no músculo branco dos peixes ocorre principalmente a glicólise anaeróbica para suprir necessidades energéticas, enquanto que na musculatura vermelha predominam vias aeróbicas, incluindo a alta atividade do ciclo 
do ácido cítrico e fosforilação oxidativa (BERNAL et al., 2003; MCKENZIE et al., 2004; CLUTTERHAM et al., 2004; DALZIEL et al., 2005). No presente estudo observou o aumento de atividade da LDH em ambos os músculos, vermelho e branco, frente o agente estressor; porem esse aumento foi mais pronunciado no músculo vermelho.

Estudos realizados por Almeida (2001) para juvenis de tilápia do Nilo expostos ao agente estressor cádmio mostraram valores significativamente maiores de atividade de LDH. Esta enzima é um fator importante na habilidade de alguns peixes de produzir impulsos repentinos de natação (jatos), e é encontrada em grandes quantidades na musculatura vermelha quando há um maior investimento metabólico na locomoção (BRIGHTMAN et. al., 1997).

De acordo como o exposto no presente capítulo conclui-se que houve uma relação direta entre o estresse de contenção de tilápia do Nilo e alterações bioquímicas nos músculos do peixe, principalmente no filé, a parte nobre do animal.

\subsubsection{Efeitos do licopeno sobre parâmetros zootécnicos e bioquímicos de juvenis de tilápia do Nilo (Oreochromis niloticus) submetidos a estresse por contenção.}

Varias técnicas são adotadas para minimizar os efeitos negativos do estresse sobre a qualidade e produtividade animal. Os resultados do presente estudo sugerem que a suplementação com licopeno protege a tilápia do Nilo contra os efeitos negativos do estresse de contenção. 
Em termos da concentração de cortisol plasmático observa-se na Figura 11 que os animais submetidos à contenção e suplementados com licopeno não apresentaram alteração deste parâmetro $(15,12 \pm 2,43 \mathrm{ng} / \mathrm{mL})$, comparativamente ao controle $(16,72 \pm 2,81 \mathrm{ng} / \mathrm{mL})$. Embora o desafio de estresse por 90 minutos utilizado neste estudo tenha sido efetivo, provocando um aumento de $53 \%$ na concentração de cortisol plasmático dos peixes do grupo controle.

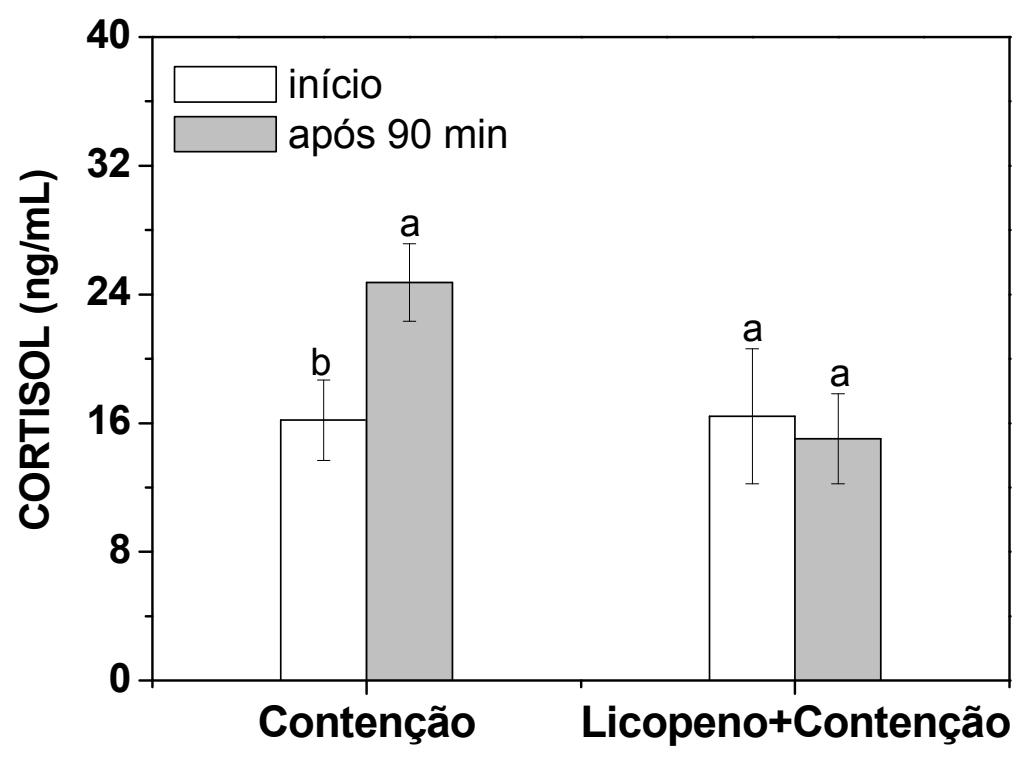

Figura 11 - Efeito da suplementação com licopeno (800 mg/kg de ração) sobre os níveis de cortisol plasmático de juvenis de tilápia do Nilo (Oreochromis niloticus) submetidos a estresse de contenção (90 minutos). Resultados expressos como média e desvio padrão ( $n=10$ animais/tratamento) Para cada grupo avaliado, letras diferentes indicam diferença ao nível de significância de 5\%.

Não existem estudos relacionando a suplementação com licopeno e a supressão de hormônios em animais de criação intensiva. Porém, estudos com ratos mostraram os efeitos positivos da suplementação com antioxidantes, como o 
licopeno e $\beta$-caroteno, sobre a manutenção em níveis basais da concentração de cortisol após submeter os animais a um agente estressor (EL-DEMERDASH et.al., 2004; BESTAS et. al., 2008).

Outros estudos mostraram os efeitos benéficos da suplementação com vitaminas $\mathrm{C}$ e $\mathrm{E}$ em humanos, reduzindo os danos causados pelo estresse oxidativo provocados por exercícios físicos (URSO e CLARKSON, 2003). Sendo, a suplementação com vitamina C segundo Peters et. al., (2001) atenuante dos hormônios, cortisol e adrenalina, gerados em resposta ao exercício físico. No presente estudo, a inclusão de licopeno na ração de tilápia atenuou o nível de cortisol produzido em resposta ao desafio de contenção.

Segundo Omoni e Aluko (2005) a inclusão de licopeno na dieta de humanos favorece a função antioxidante do organismo por remover as ERO e evitar a peroxidação lipídica.

Muitos estudos estabelecem uma condição positiva para os parâmetros zootécnicos o bem-estar animal. A condição de estresse de contenção, como descrito no presente estudo, não alterou os parâmetros zootécnicos (Tabela 5). Estes resultados eram esperados, uma vez que os animais foram eutanasiados logo após o desafio. Por outro lado, estes resultados são importantes para ilustrar a igualdade de condições experimentais para todos os grupos estudados. Uma vez que não foram observadas diferenças significativas em nenhum dos parâmetros zootécnicos avaliados entre os três grupos de peixes: controle; suplementado com licopeno e o suplementado com licopeno e submetido ao desafio de contenção. 
Tabela 5 - Efeito da suplementação com licopeno (800 mg/kg de ração) sobre o desempenho de juvenis de tilápia do Nilo (Oreochromis niloticus) submetidos a estresse de contenção (90 minutos).

\begin{tabular}{|c|c|c|c|}
\hline Parâmetros & Controle & $\begin{array}{l}\text { Controle + } \\
\text { Contenção }\end{array}$ & $\begin{array}{l}\text { Licopeno + } \\
\text { Contenção }\end{array}$ \\
\hline GP & $20,58 \pm 7,61^{a}$ & $13,49 \pm 2,34^{a}$ & $15,45 \pm 9,81^{a}$ \\
\hline CA & $1,47 \pm 0,32^{a}$ & $5,23 \pm 2,72^{a}$ & $2,03 \pm 1,24^{a}$ \\
\hline $\mathrm{FC}$ & $3,28 \pm 0,21^{a}$ & $3,28 \pm 0,40^{a}$ & $3,25 \pm 0,22^{a}$ \\
\hline TCE & $0,36 \pm 0,11^{a}$ & $0,20 \pm 0,21^{a}$ & $0,38 \pm 0,21^{a}$ \\
\hline CONSUMO & $23,9 \pm 8,37^{a}$ & $17,3 \pm 7,44^{a}$ & $22,9 \pm 6,14^{a}$ \\
\hline
\end{tabular}

Os parâmetros zootécnicos são características importantes a serem avaliadas em animais de criação intensiva, principalmente do ponto de vista econômico. Estudos envolvendo a suplementação com antioxidantes na dieta de animais de interesse comercial mostram significativa melhora na produtividade, qualidade do produto final (PASCHOAL et.al., 2006; CASTILLO et.al., 2005; HAVEMOSE et.al., 2004; VALLE, 2005). No presente estudo, a inclusão de licopeno na ração de tilápia não alterou os parâmetros zootécnicos, mas, se tornou importante quanto ao seu potencial valor antioxidante. 
Estudos envolvendo suplementação de tilápia demonstram que a vitamina $E$ atua como antioxidante inibindo a peroxidação lipídica no filé (HUANG, et. al., 2004a). Segundo Huang e Huang, (2004b) a suplementação com vitamina E oferece uma ferramenta para combater os danos causados pelo estresse oxidativo, o que reflete diretamente na qualidade do file da tilápia.

Observou-se, no presente estudo, que a inclusão de licopeno na ração de tilápia do Nilo inibiu os efeitos negativos do estresse de contenção sobre a peroxidação dos lipídeos do filé.

Conforme apresentado na Figura 12, observou-se que o estresse de contenção provocou um aumento de $28 \%$ no nível de oxidação lipídica do filé dos peixes não suplementados com licopeno $(5,48 \pm 0,47 \mathrm{nmol} / \mathrm{g}$ de tecido úmido), comparativamente ao grupo controle (peixes não estressados; 4,28 $\pm 0,41 \mathrm{nmol} / \mathrm{g}$ de tecido úmido). Por outro lado, os níveis de TBARS dos peixes suplementados com licopeno $(4,30 \pm 0,50 \mathrm{nmol} / \mathrm{g}$ de tecido úmido) não foram alterados pelo estresse de contenção, sugerindo efeito protetor desta substância. 


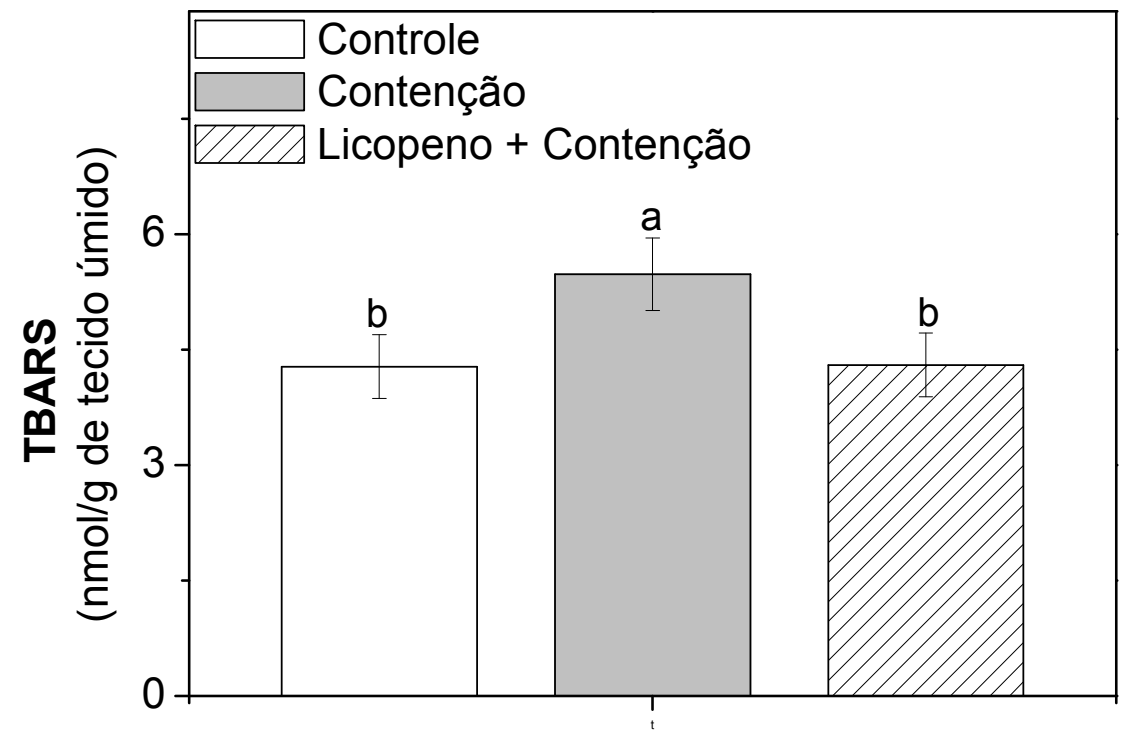

Figura 12 - Efeito da suplementação com licopeno (800 mg/kg de ração) sobre o conteúdo de substâncias reativas ao ácido tiobarbitúrico (TBARS) no músculo branco (filé) de juvenis de tilápia do Nilo (Oreochromis niloticus) submetidos a estresse de contenção (90 minutos). Resultados expressos como média e desvio padrão ( $n=10$ animais/tratamento). Letras diferentes indicam diferença ao nível de significância de $5 \%$.

Estudos envolvendo suplementação de peixes demonstraram resultados positivos ao usar antioxidantes, em especial da vitamina $E$, refletindo nas propriedades antioxidantes que incidem diretamente no desempenho e nas características desejáveis para uma boa qualidade do peixe (TRENZADO et. al., 2007).

A cor instrumental do filé de tilápia não foi alterada no grupo de peixes suplementado com licopeno e submetido ao desafio de contenção, similar aos resultados encontrados para o grupo controle e grupo submetido somente ao estresse (sem licopeno) (Tabela 6). 
Tabela 6 - Efeito da suplementação com licopeno (800 mg/kg de ração) sobre parâmetros de cor instrumental da carne de juvenis de tilápia do Nilo (Oreochromis niloticus) submetidos a estresse de contenção (90 minutos).

\section{Parâmetros Controle Controle + Contenção Licopeno + \\ Contenção}

\begin{tabular}{|c|c|c|c|}
\hline$L$ & $55,16 \pm 2,23^{a}$ & $54,24 \pm 1,63^{a}$ & $54,53 \pm 2,20^{a}$ \\
\hline$a$ & $2,31 \pm 0,98^{a}$ & $2,49 \pm 0,62^{a}$ & $2,11 \pm 0,53^{a}$ \\
\hline$b$ & $9,74 \pm 0,95^{a}$ & $9,81 \pm 0,70^{a}$ & $9,83 \pm 0,65^{a}$ \\
\hline
\end{tabular}

A função benéfica das vitaminas $E$ e $C$ na modulação do estresse oxidativo em peixes tem despertado recente interesse nos pesquisadores (MERCHIE et. al., 1997; MONTERO et. al., 2001; KOLKOVSKI et. al., 2000; ORTUÑO et. al., 2003; PRIETO et. al., 2008).

Em ratos o licopeno apresentou ação protetora aos danos decorrentes do estresse oxidativo causado por ferro no intestino e próstata (REIFEN et. al., 2004; MATOS et. al., 2006), protegeu também contra nefrotoxicidade, cardiotoxicidade e danos testiculares produzidos por adrimicina (YILMAZ et. al., 2006; ATEAHIM et. al., 2006).

No presente estudo, a inclusão de licopeno na dieta de tilápia mostrou resultados positivos, também, sobre a proteção antioxidante do filé e músculo 
vermelho de animais submetidos ao desafio de contenção, avaliado pelas atividades das enzimas antioxidantes catalase e glutationa redutase (Figura 13).

Conforme os resultados apresentados na Figura 13, a atividade da catalase no filé dos animais suplementados com licopeno e subsequente exposição à contenção $(1,73 \pm 0,29 \mu \mathrm{mol} / \mathrm{min} / \mathrm{mg}$ de proteína) não teve diferença significativa em relação ao grupo controle $(1,77 \pm 0,35 \mu \mathrm{mol} / \mathrm{min} / \mathrm{mg}$ de proteína). Entretanto, apresentou diferença significativa quando comparado ao grupo submetido apenas ao desafio de contenção $(2,32 \pm 0,21 \mu \mathrm{mol} / \mathrm{min} / \mathrm{mg}$ de proteína). Estes resultados mostram a ação protetora do licopeno frente aos efeitos do estresse de contenção sobre a catalase no filé.

Similarmente ao encontrado no filé, a atividade de catalase no músculo vermelho dos peixes suplementados com licopeno e submetidos ao estresse $(3,33 \pm 0,80 \mu \mathrm{mol} / \mathrm{min} / \mathrm{mg}$ de proteína) não apresentou diferença significativa quando comparada ao resultado do grupo controle $(3,02 \pm 029 \mu \mathrm{mol} / \mathrm{min} / \mathrm{mg}$ de proteína), já em relação ao grupo de animais submetidos ao desafio de contenção (sem licopeno) $(4,45 \pm 0,48 \mu \mathrm{mol} / \mathrm{min} / \mathrm{mg}$ de proteína) verificou-se diferença significativa.

Em relação à atividade da glutationa redutase, o licopeno incorporado à dieta da tilápia protegeu tanto o filé quanto o músculo vermelho do animal exposto ao desafio de contenção.

Não houve diferença significativa entre os valores de atividade da glutationa redutase avaliada no filé de tilápia do Nilo suplementada com licopeno e submetida ao estresse de contenção $(1,66 \pm 0,29 \mathrm{nmol} / \mathrm{min} / \mathrm{mg}$ de proteína) comparada ao grupo controle $(1,80 \pm 0,21 \mathrm{nmol} / \mathrm{min} / \mathrm{mg}$ de proteína). Embora, quando comparado 
ao grupo controle submetido à contenção $(2,37 \pm 0,23 \mathrm{nmol} / \mathrm{min} / \mathrm{mg}$ de proteína) verificou-se diferença significativa.

A atividade da glutationa redutase no músculo vermelho, também não apresentou diferença entre os valores obtidos do grupo licopeno-contenção $(3,39 \pm$ 0,44 $\mathrm{nmol} / \mathrm{min} / \mathrm{mg}$ de proteína) e grupo controle $(3,21 \pm 0,58 \mathrm{nmol} / \mathrm{mi} / \mathrm{mg}$ de proteína), entretanto, foi obtida diferença significativa entre ambos os grupos licopeno+contenção e o controle submetido à contenção $(4,70 \pm 0,69 \mathrm{nmol} / \mathrm{min} / \mathrm{mg}$ de proteína). 

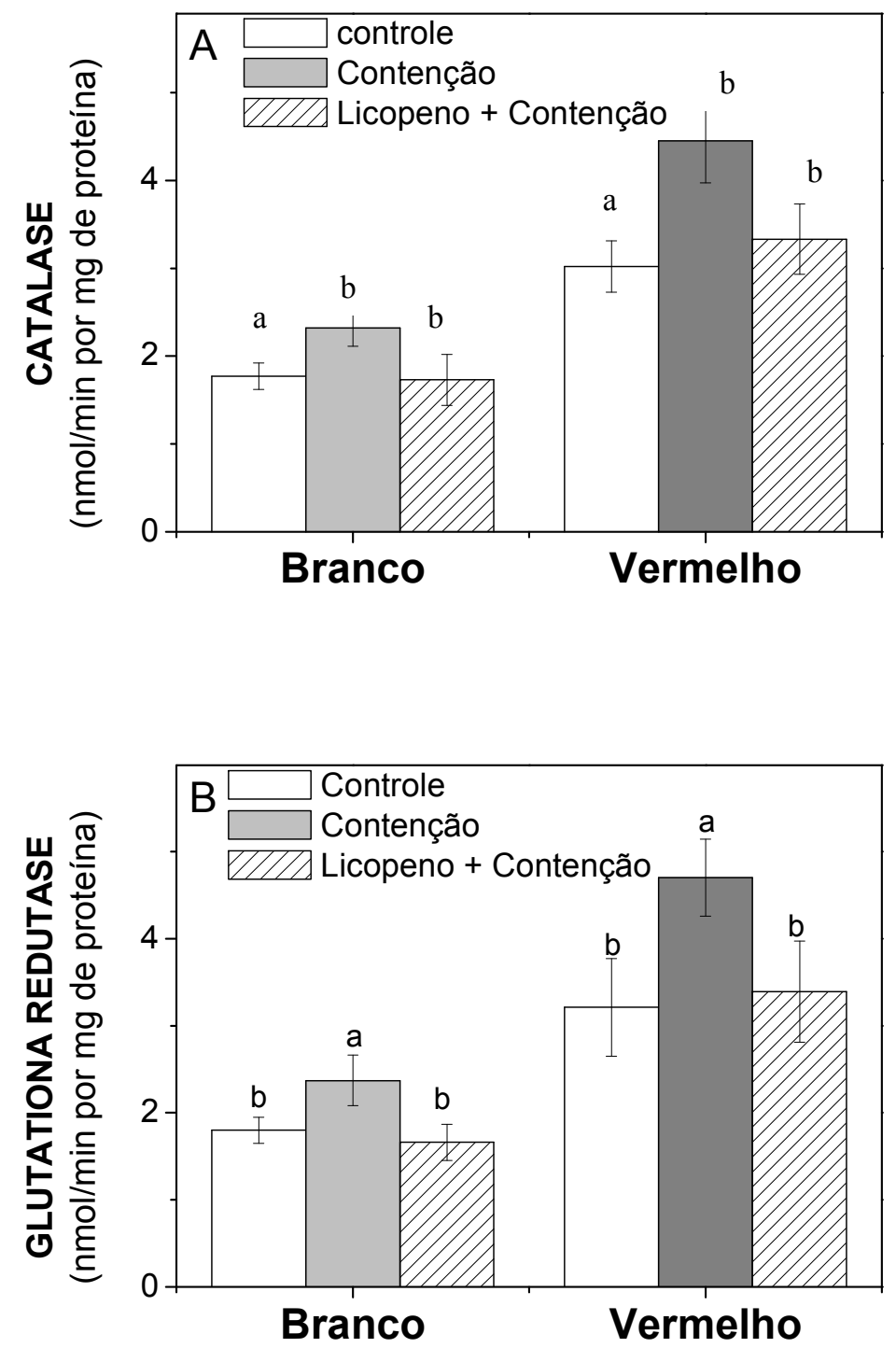

Figura 13 - Efeito da adição de licopeno ( $800 \mathrm{mg} / \mathrm{kg}$ de ração) durante 60 dias sobre a atividade de enzimas antioxidantes presentes em músculo branco e vermelho de juvenis de tilápias do Nilo (Oreochromis niloticus). (A) Atividade da catalase e (B) Atividade da glutationa redutase e subsequentemente exposto a contenção. Resultados expressos como média e desvio padrão ( $n=10$ animais/tratamento). Para cada grupo de músculo, letras diferentes indicam diferença ao nível de significância de $5 \%$. 
Estudos mostram que exposição de tilápia do Nilo a agentes estressores químicos aumentam a atividade de catalase (BASHA e RANI, 2003, PEIXOTO et. al., 2006 e PRIETO et. al., 2007, 2008). Resultados similares foram também encontrados em caranguejos (PINHO et. al., 2005). Entretanto, Atencio et. al., (2009) em seus estudos avaliaram a ação do selênio como um possível suplemento para juvenis de tilápia do Nilo expostos a cianobactérias, revelando resultado protetor do selênio quanto à diminuição da atividade de catalase avaliada em fígado e rins. No presente estudo, foram encontrados resultados semelhantes pela suplementação da tilápia do Nilo com licopeno.

Quanto ao aumento na atividade da LDH conferida pelo estresse de contenção de tilapia do Nilo, os resultados apresentados na Figura 14 mostram que esta enzima é menos sensível aos efeitos do estresse de contenção quando avaliada no filé que no músculo vermelho. Assim, a suplementação do animal com licopeno não protegeu o file de tilápia contra os efeitos do estresse de contenção; mas, entretanto, evitou a ação da contenção sobre a atividade de LDH no músculo vermelho.

A suplementação de tilápia do Nilo com licopeno não apresentou resultado positivo quanto ao desafio de contenção avaliado pela atividade de LDH no filé. Não houve diferença significativa entre a atividade da LDH no filé dos animais submetidos ao desafio de contenção $(14,00 \pm 1,37 \mu \mathrm{mol} / \mathrm{min} / \mathrm{mg}$ de proteína) e licopeno+contenção $(12,69 \pm 1,44 \mu \mathrm{mol} / \mathrm{min} / \mathrm{mg}$ de proteína) (Figura 14).

Entretanto, foi verificado que não houve diferença significativa entre os valores de atividade de LDH para o músculo vermelho dos animais suplementados com licopeno e submetidos ao desafio de contenção $(11,19 \pm 1,68 \mu \mathrm{mol} / \mathrm{min} / \mathrm{mg}$ de 
proteína) quando comparados aos do grupo controle $(11,37 \pm 1,00 \mu \mathrm{mol} / \mathrm{min} / \mathrm{mg}$ de proteína), porém, apresentaram diferença significativa em relação aos do grupo submetido à contenção $(16,31 \pm 1,52 \mu \mathrm{mol} / \mathrm{min} / \mathrm{mg}$ de proteína) (Figura 14). Estes resultados mostram o efeito do protetor do licopeno sobre a manutenção em níveis normais a atividade de LDH no músculo vermelho.

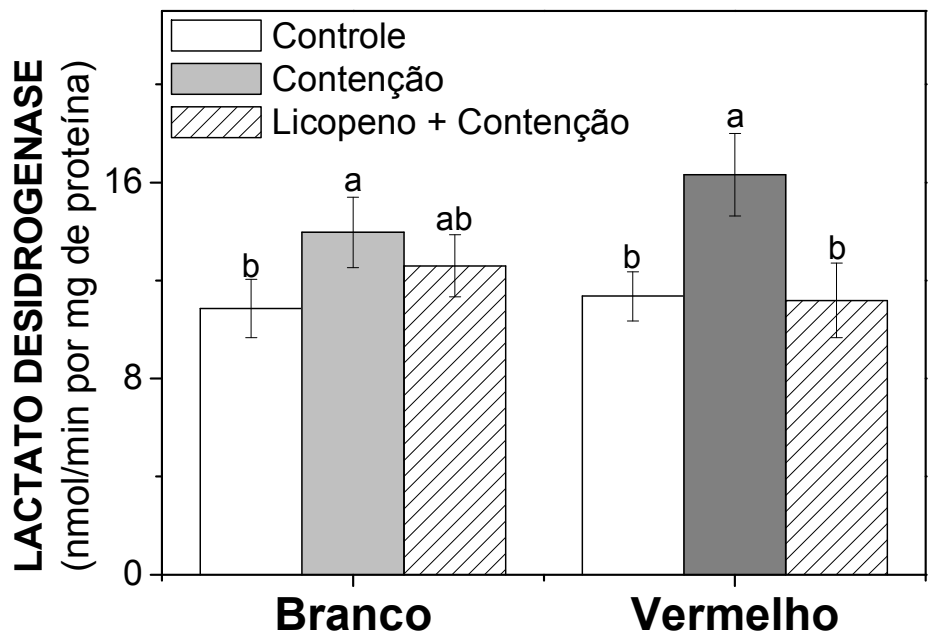

Figura 14 - Efeito da adição de licopeno (800 mg/kg de ração) durante 60 dias sobre a atividade da lactato desidrogenase presente em músculo branco e vermelho de juvenis de tilápias do Nilo (Oreochromis niloticus) e subsequentemente exposto a contenção. Resultados expressos como média e desvio padrão ( $n=10$ animais/tratamento). Para cada grupo de músculo, letras diferentes indicam diferença ao nível de significância de $5 \%$.

A manutenção da atividade das enzimas catalase, glutationa redutase e LDH nos músculos de juvenis de tilápia do Nilo suplementados com licopeno, mesmo após o estresse de contenção, sugere um efeito protetor deste antioxidante. 
Muitos estudos têm sido conduzidos a fim de utilizar o potencial benéfico do licopeno e a maioria relaciona o efeito protetor do carotenóide à sua atividade antioxidante. Porém, a maioria dos estudos foram realizados quase que exclusivamente em ratos e humanos.

Para tilápia do Nilo os resultados apresentados nesta tese mostram o efeito protetor do licopeno ao estresse de contenção evidenciado nos parâmetros fisiológicos e bioquímicos, sobretudo, na qualidade do filé; sugerindo o uso potencial deste carotenóide na suplementação de peixes. 


\section{CONCLUSÕES}

1. O licopeno, na proporção em até $800 \mathrm{mg} / \mathrm{kg}$, não altera a atrato-palatabilidade da ração comercial para tilápia do Nilo.

2. A contenção por redução do nível de água é uma ferramenta adequada para se realizar estudos sobre os efeitos do estresse em juvenis de tilápia do Nilo, pois, promove aumento do nível de cortisol, da oxidação lipídica e da atividade das enzimas que caracterizam o estresse fisiológico e oxidativo.

3. O licopeno veiculado na ração comercial, na proporção de $800 \mathrm{mg} / \mathrm{kg}$, não afeta a coloração do filé, porém, atua como um agente antioxidante, protegendo juvenis de tilápia do Nilo dos efeitos negativos do estresse.

4. O licopeno reduz os efeitos negativos do estresse não afetando o desempenho de juvenis da tilápia do Nilo, Oreochromis niloticus. 


\section{REFERENCIAS BIBLIOGRAFICAS}

ABELE, D.; PUNTARULO, S. Formation of reactive species and induction of antioxidant defence systems in polar and temperate marine invertebrate and fish. Comparative Biochemestry and Physiology v. 38A, p. 405-415, 2004.

ADAMS, M. A.; JOHNSEN, P. B.; HONG-QI, Z. Chemical enhencement of feeding for the herbivorous fish Tilapia zillii. Aquaculture, v.72, n.1, p.95-107, 1988.

AGARWAL, S., \& RAO, V. A. Tomato lycopene and its role in human health and chronic diseases. Canadian Medical Association Journal, v.163, p.739-744, 2000 .

AHMAD, I., HAMID, T., FATIMA, M., CHAND, H.S., JAIN, S.K., ATHAR, M., RAISUDDIN, S., Induction of hepatic antioxidants in freshwater catfish (Channa punctatus Bloch) is a biomarker of paper mill effluent exposure. Biochimica et Biophysica Acta, v.1519, p. 37-48, 2000.

AKERMAN, G.; AMCOFF, P.; TJARNLUND, U.; FOGELBERG K.; TORRISEN O.; BALK, L. Paraquat and menadione exposure of rainbow trout (Oncorhynchus mykiss). Studies of effects on the pentose-phosphate shunt and thiamine levels in liver and kidney, Chemico-Biological Interactions. v.142, p.269-283, 2003.

AL-BANDAK, G.; TSIRONI, T.; TAOUKIS, P.; OREOPOULOU, V. Antimicrobial and antioxidant activity of Majorana syriaca in Yellowfin tuna. International Journal of Food Science and Technology, v.44, p.373-379, 2009.

ALMEIDA J.D.; DINIZ, Y.S.; MARQUES, S.F.; FAINE, L.A.; RIBAS, B.O.; BURNEIKO, R.C.; NOVELLI E.L. The use of the oxidative stress responses as biomarkers in Nile tilapia (Oreochromis niloticus) exposed to in vivo cadmium contamination. Environment International. v.8, n.27, p.673-679, 2002.

ALMEIDA, J. D. Enviromental cadmium exposure and metabolic response of tilapia do nilo. Environmental pollution, v.114, pp.169-175, 2001.

ALVES, S.R.C., SEVERINO, P.C., IBBOTSON, D.P. Effects of furadan in the brown mussel Perna perna and in the mangrove oyster Crassostrea rhizophorae. Marine Environmental Research, v.54, pp. 1-5, 2002. 
AMAR, E. C.; KIRON, V.; SATOH, S.; OKAMOTO, N.; WATANABE, T. Effects of dietary $\beta$ carotene on the inmune response of rainbow trout (Oncorhynchus mykiss). Fisheries Science. v. 66, p. 1068-1075, 2000.

AMARAL MONTEIRO, D.; ALVES DE ALMEIDA, J.; TADEU RANTIN, F.; KALININ, A. L. Oxidative stress biomarkers in the freshwater characid fish, Brycon cephalus, exposed to organophosphorus insecticide Folisuper 600 (methyl parathion) Comparative Biochemistry and Physiology, Part C v.143, p.141149, 2006.

AMSLAD, P.; MORETI, R.; CERUTTI, P. Glutathione peroxidase compensates for the hypersensitivity of $\mathrm{Cu}, \mathrm{Zn}$ superoxide dismutase over producers to oxidant stress. Journal Biological Chemical, v.269, p.1606-1609, 1994.

ARAB, L., e STECK, S. Lycopene and cardiovascular disease. American Journal of Clinical Nutrition, v.71, p.1691-1695, 2000.

ASHIDA, T.; TAKEI, Y.; TAKAGAKI, M.; MATSUURA, Y.; OKIMASU, E. The dietary effects of a fermented vegetable product on glutathione peroxidase activity and lipid peroxidation of Japanese flounder Paralichthys olivaceus Fisheries Science v.72, p. 179-184, 2006.

ATENCIO, L.; MORENO, I.; JOS, A.; PRIETO, A.; MOYANO, R.; BLANCO, A.; CAMEAN, A. M. Effects of dietary selenium on the oxidative stress and pathological changes in tilapia (Oreochromis niloticus) exposed to a microcystinproducing cyanobacterial water bloom. Toxicon, v.53, p.269-282, 2009.

ATENCIO, L.; MORENO, I.; JOS, A.; PRIETO, A.; MOYANO, R.; BLANCO, A.; CAMEAN, A. Effects of dietary selenium on the oxidative stress and pathological changes in tilapia (Oreochromis niloticus) exposed to a microcystin-producing cyanobacterial water bloom Toxicon, v.53, p.269-282, 2009.

ATLI, G.; CANLI, M. Enzymatic responses to metal exposures in a freshwater fish Oreochromis niloticus Comparative Biochemistry and Physiology, Part C v.145, pp.282-287, 2007.

BALON, E. K. Defending fish against recreational fishing: an old problem to be solved in the new millennium. Environmental Biology of Fishes v.57, p.1-8, 2000. 
BARJA DE QUIROGA, G., Brown fat thermogenesis and exercise: two examples of physiological oxidative stress?. Free Radical Biological Medicinal, v. 13, p. 32540, 1992.

BARRETO, R. G.; VOLPATO, G.L.; BRITO FATURI, C.; GIAQUINTO, P. . GONÇALVES DE FREITAS, E.; FERNANDES DEL CASTILHO, M. Agressive behaviour traits predict physiological stress responses in Nile tilapia (Oreochromis niloticus), Marine and Freshwater Behaviour and Physiology, v. 42, n. 2, p. 109-118, 2009

BARRETO, R. E.; VOLPATO, G. L. Caution for using ventilatory frequency as an indicator of stress in fish. Behavioural Processes, v.66, p. 43-51, 2004.

BARTON, B. A.; IWANA, G.K. Physiological changes in fish from stress in aquaculture with emphasis on the response and effects of corticosteroids. Annual Review of Fish Diseases, v. 10, p.3-26, 1991.

BASHA, P.S. RANI, A.U. Cadmium-induced antioxidant defense mechanism in freshwater teleost Oreochromis mossambicus (Tilapia). Ecotoxicoly and Environmental Safety. v.2, n.56, p.218-221, 2003.

BEERS, R. F., SIZER, I. W. A spectophotometric method for measuring the breakdown of hydrogen peroxide by catalase. Journal of Biological Chemistry, v.195(1), p.133-140, 1952.

BEKHIT, A. E. D.; ILIAN, M. A.; MORTON, J. D.; VANHANAN, L.; SEDCOLE J. R.; BICKERSTAFFE, R. Effect of calcium chloride, zinc chloride, and water infusion on metmyoglobin reducing activity and fresh lamb color. American Society of Animal Science. v. 83, p. 2189-2204, 2005.

BEKOF, M. Why "good welfare" isn't "good enough": minding animals and increasing our compassionate footprint. Annual Review of Biomedical Sciences. v.10, p.114, 2008.

BELL, J. G.; MCEVOY, J.; TOCHER D. R.; SARGENT, J. R. Depletion of atocopherol and astaxanthin in Atlantic salmon (Salmo salar) affects autoxidative defense and fatty acid metabolism. Journal of Nutrition v.130, p.1800-1808, 2000. 
BELO, M. A. A.; SCHALCH, S. H. C.; MORAES, F. R.; SOARES, V. E.; OTOBONI, A. M. M. B.; MORAES, J. E. R. Effect of dietary supplementation with vitamin E and stocking density on macrophage recruitment and giant cell formation in the teleost fish, Piaractus mesopotamicus. Journal of Comparative Pathology. v.133, p.146-154, 2005.

BEN-AMOTZ, A., e FISHLER, R. Analysis of carotenoids with emphasis on 9-cis bcarotene in vegetablesand fruitscommonly consumed in Israel. Food Chemistry, v.62, n.4, p.515-520, 1998.

BERNAL, D.; SMITHD.; LOPEZ, G. WEITZ, D.; GRIMMINGER, T.; DICKSON, K.; GRAHAM, J.B. Comparative studies of high performance swimming in sharks II. Metabolic biochemistry of locomotor and myocardial muscle in endothermic and ectothermic sharks. Experimental Biology. v.16, n.206, p.2845-2857, 2003.

BERNT, E., BERGMEYER, H. U. Lactate desydrogenase assay. In: Bergmeyer, H.U. (Ed), Methods of Enzymatic Analysis, Academic Press, London, 1974.

BESTAS, A.; KAHRAMANOGLU, M.; ERHAN, O. L.; BOLAT, E.; OZERCAN, I.; GURSU, F.; GULCU, F. The role of the antioxidants lycopene and vitamin E in the prevention of halothane-induced hepatotoxicity. Methods and Findings in Experimental and Clinical Pharmacology, v.30, n.8, p.627-631, 2008.

BJERKENG, B.; HATLEN, B.; WATHNE, E. Deposition of as-taxanthin in diets of Atlantic salmon (Salmo salar) fed diets with herring, capelin, sandeel, or Peruvian high PUFAoils. Aquaculture, v.180, p.307-319, 1999.

BOILEAU, A. C., MERCHEN, N. R.,WASSON, K., ATKINSON, C. A., \& ERDMAN, J. W. Cis-lycopene is more bioavailable than trans-lycopene in vitro and in vivo in lymph-cannulated ferrets. Journal of Nutrition, v.129, p.1176-1181, 1999.

BONGA, S.E.W. The stress response in fish. Physiological Review, v.77, p.591625. 1997.

BOWEN, J.; SOUTAR, C.; SERWATA, R. D.; LAGOCKI, S.; WHITE, D. A.; DAVIES, S. J.; YOUNG, A. J. Utilization of astaxanthin acyl esters in pigmentation of rainbow trout (Oncorhynchus mykiss). Aquaculture Nutrition, v.8, p.59-68, 2002.

BRAGA, F. M.S. Estudo entre fator de ocndiçãoe relação peso/comprimento para alguns peixes marinhos. Revista Brasileira de Biologia, v.46, p. 339-346, 1986 
BRAITHWAITE, V. A.; BOULCOTT, P. Pain perception, aversion and fear in fish. Diseases of Aquatic Organisms. v.75, p.131-138, 2007.

BRAMLEY, P. M. Is lycopene beneficial to human health? Phytochemistry, v.54, p.233-236, 2000.

BRIGHTMAN, R. I., TORRES, J. J., DONELLY, J. CLARKE, M. E. ENERGETICS OF LARVAL RED DRUM Scianops ocellatus. Part II. Growth and biochemical indicators. Fishery Bulletin v.95, p. 431-444, 1997.

BROOM, D.M. Welfare assessment and relevant ethical decisions: key concepts. Annual Review of Biomedical Sciences. v.10, p. 79-90, 2008.

BUEGE, J. A.; AUST, S. D. The thiobarbuturic acid assay. Methods Enzymol v. 52, p. 306-307, 1978.

CADENAS, E. Mechanisms of oxygen activation and reactive oxygen species detoxification In: AHMAD, S. (ed.), Oxidative stress and Antioxidant Defenses in Biology. Chapman \& Hall, New York, p. 1-46, 1995.

CADENAS, S.; DAVIES, K. J. A. Mitochondrial free radical generation, oxidative stress and aging. Free Radical Biology Medicine, v.29, p. 222-230, 2000.

CALBERG, I., MANNERVICK, B. Glutathione reductase. Methods in Enzymology, Academic Press, New York, p.484-490, 1985.

CASTILLO, C.; HERNANDEZ, J.; BRAVO, A.; LOPEZ-ALONSO, M.; PEREIRA, V. BENEDITO, J. L. Oxidative status during late pregnancy and early lactation in dairy cows. The Veterinary Journal. v. 169, p. 286-292, 2005.

CAZENAVE, J.; BISTONI, M. A.; PESCE, S. F.; WUNDERLIN, D. A. Differential detoxification and antioxidant response in diverse organs of Corydoras paleatus experimentally exposed to microcystin-RR Aquatic Toxicology. v.76, p. 1-12, 2006.

CHANCE, B.; WILLIAMS, G. R. The respiratory chain and oxidative phosphorylation. Advances in Enzymology. v.17, p. 65-134, 1956.

CHANDROO K.P., DUNCAN I.J.H., MOCCIA R.D. Can fish suffer?: perspectives on sentience, pain, fear and stress. Applied Animal Behaviour Science v.86, p.225-250, 2004. 
CHEN, R.; LOCHMANN, R.; GOODWIN, A.; PRAVEEN, K.; DABROWSKI, K.; LEE, K. J. Effects of dietary vitamins $C$ and $E$ on alternative complement activity, hematology, tissue composition, vitamin concentrations and response to heat stress in juvenile golden shiner (Notemigonus crysoleucas). Aquaculture. v.242, p.553-569, 2004.

CHUN, S.S.; VATTEM, D. A.; LIN, Y. T.; SHETTY, K. Phenolic antioxidants from clonal oregano (Origanum vulgare) with antimicrobial activity against Helicobacter pylori. Process Biochemistry. v.40, p. 809-816, 2005.

CLUTTERHAM, S.; GAMPERL, A.K.; WALLACE, H.L.; CRAWSHAW, L.I.; FARRELL, A.P. Exhaustive exercise does not affect the preferred temperature for recovery in juvenile rainbow trout (Oncorhynchus mykiss). Physiological and Biochemical Zoology.v.4, n.77, p. 611-618, 2004.

COHEN, L.A. A review of animal model studies of tomato carotenoids, lycopene, and cancer chemoprevention. Experimental Biology and Medicine. V.227, p.864868, 2002.

CONTE, F. S. Stress and the welfare of cultured fish. Applied and animal behaivor science v.86, p.205-223, 2004.

CORNELIUS, J. G.; LUTTGE, B. G.; PECK, A. B. Antioxidant enzyme activities in idprone and idd-resistent mice:a comparative study. Free Radical Biology Medicine, v.14, p.409-420, 1993.

CORSINO, J.; SILVA, D. H. S.; ZANONI, M. V. B.; BOLZANI, V.S.; FRANÇA S. C.; , PEREIRA, A. M. S.; FURLAN, M. Antioxidant Flavan-3-ols and Flavonol Glycosides from Maytenus aquifolium. Phytotherapy Research. v. 17, p. 913916, 2003

COSTAS, B.; ARAGÃO, C.; MANCERA, J.M. et al. High stocking density induces crowding stress and affects amino acid metabolism in Senegales sole Sole senegalensis (Kaup 1858) juveniles. Aquaculture Research, v.39, p.1-9, 2008.

DALZIEL, A.C.; MOORE, S.E.; MOYES, C.D. Mitochondrial enzyme content in the muscle of high-performance fish: evolution and variation among fiber types. American Journal of Physiology Regulatory Integrative and Comparative Physiology. 288, 163-172, 2005. 
DAVIS, K.B.; TORRANCE, P.; PARKER, N.C.; SUTTLE, M.A. Growth, body composition, e hepatic tyrosine aminotransferase activity in cortisol-fed channel catfish, Ictalurus punctatus R. Journal of Fish Biology, v.27, p.177-184, 1985.

DAWKINS, M.S. The science of animal suffering. Ethology. v. 114, p. 937-945, 2008.

DESHPANDE, S.S.; SANTHE, S.K.; SALUNKHE, D.K. Chemistry and safety of plants polyphenols. Advances in Experimental Medicine and Biology. v. 177, p. 457-495, 1984.

DI MASCIO, P., KAISER, S., e SIES, H. Lycopene as the most efficient biological carotenoid singlet oxygen quencher. Archives of Biochemistry and Biophysics, v.274, p.532-538, 1989.

DRÖGE, W. Free radicals in the physiological control of cell function. Physiological Reviews. v. 82 p. 47-95, 2002.

DUARTE, J.A.; APPELL, H.J.; CARVALHO, F.; SOARES, J.M. Endothlium-derived oxidative stress may contribute to exercise-induced muscle damage. International Journal of Sports Medicine. v.14, p. 440-3, 1993.

DUNCAN, I. J. H. The changing concept of animal sentience. Applied Animal Behaviour Science. v.100, p.11-19, 2006.

EL-DEMERDASH, F. M.; YOUSEF, M. I.; KEDWANY, F. S.; BAGHDADI, H. H. Cadmium-induced changes in lipid peroxidation, blood hematology, biochemical parameters and semen quality of male rats: protective role of vitamin $E$ and $b$ carotene. Food and Chemical Toxicology, v.42, p.1563-1571, 2004.

FENSTER, C.P.; WEINSIER, R.L.; DARLEY-USMAR, V.M.; PATEL, R.P. Obesity, aerobic exercise and vascular disease: the role of oxidante stress. Obesity Research. v.10, p. 964-968, 2002.

FERNANDES, M.O. Estresse social, metabolismo e crescimento em peixes. (Tese - Doutorado), universidade Estadual Paulista, UNESP, Botucatu, p. 82, 1997.

FERRARI, A.; VENTURINO, A.; PECHÉN DE D'ANGELO, A. M. Effects of carbaryl and azinphos methyl on juvenile rainbow trout (Oncorhynchus mykiss) detoxifying enzymes. Pesticide Biochemistry and Physiology. v. 88, p. 134-142, 2007. 
FERREIRA, A.L.A.; MATSUBARA, L.S. Radicais Livres: conceitos, doenças relacionadas, sistema de defesa e estresse oxidativo. Revista da Associação Médica Brasileira, v. 43, p. 61-68, 1997.

FERREIRA, M.; MORADAS-FERREIRA, P.; REIS-HENRIQUE, M.A. Oxidative stress biomarkers in two resident species, mullet (Mugil cephalus) and flounder (Platichthys flesus), from a polluted site in River Douro Estuary, Portugal. Aquatic Toxicology. v.1, n.71, p.39-48, 2005.

FIGUEIREDO-FERNANDES, A.; FONTAINHAS-FERNANDES, A.; PEIXOTO, F.; ROCHA, E.; REIS-HENRIQUES, M.A. Effects of gender and temperature on oxidative stress enzymes in Nile tilapia Oreochromis niloticus exposed to paraquat. Pesticide Biochemistry and Physiology v.85, pp.97-103, 2006.

FRASER, D. Toward a global perspective on farm animal welfare. Applied Animal Behaviour Science, v.113, p. 330-333, 2008.

FRIGG, M.; PRABUCKI, A. L.; RUHEDL, E. U. Effects of dietary vitamin E levels on oxidative stability of trout fillets. Aquaculture, v.84, p.145-158, 1990.

FUKUMASU, H., MATSUZAKI, P.; RASPANTINI, P.C.; HARAGUCHI, M., GORNIAK, S.L.; DAGLI, M.L.Z. Inhibitory effects of Pfaffia paniculata (Brazilian ginseng) on preneoplastic and neoplastic lesions in a mouse hepatocarcinogenesis model. Cell Biochemistry and Function.; v. 226, p. 107-113, 2006.

GOLDFARB, A.H. Antioxidants: role of supplementation to prevent exercise-induced oxidative stress. Medicine and Science in Sports and Exercise. Indianapolis, v.25, n.2, p.232-236, 1993.

GÓMEZ-LAPLAZA, L. M.; GIL-CARNICERO, P. Imprinting in fish: a little explored phenomenon with possible implications for fish welfare. Annual Review of Biomedical Sciences. v.10, p. 51-62, 2008.

GUERRIERO, G.; Di FINIZIO, A.; CIARCIA, G. Stresse-induced of plasma antioxidants in aquacultured sea bass (Dicentrarchus labrax). Comparative Biochemitry and physiology. v. 132, p. 205-211, 2002.

HAKALA, S. H., e HEINONEN, I. M.. Chromatographic purication of natural lycopene. Journal of Agricultural and Food Chemistry, v.42, p.1314-1316, 1994. 
HALLIWELL, B. Free radicals and antioxidants: A personal view. Nutrition Reviews. V. 52, p. 253-65, 1994.

HALLIWELL, B.; GUTTERIDGE, J.M.C. Free Radicals in Biology and Medicine. 4ed, Oxford University Press, Oxford, UK, 2007.

HASTEIN, T.; SCARFE, A. D.; LUND, V. L. Science-based assessment of welfare: aquatic animals. Revue Scientifique et Technique de l'Office International des Epizooties. v.24, p.529-547, 2005.

HAVEMOSE, M.S.; WEISBJERG, M.R.; BREDIE W.L.P.; NIELSEN, J.H. Influence of feeding different types of roughage on the oxidative stability of milk. International Dairy Journal. v. 14, p. 563-570, 2004.

HAWLEY, J.A. Effect of increased fat availability on metabolism and exercise capacity. Medicine and Science in Sports and Exercise, v.34:9, p. 1485-1491, 2002.

HEMRE, G. I.; KROGDAHL, A. Effect of handling and size on secondary changes in carbohydrate metabolism in Atlantic salmon, Salmo salar. Aquaculture Nutrition, v.2, p.249-252, 1996.

HOGAN, J. P.; PHILIPS, C. J. C. Nutrition and the Welfare of Ruminants. Annual Review of Biomedical Sciences. v.10, p. 33-50, 2008.

HUANG, C. H.; CHANG, R. J.; HUANG, S. L.; CHEN, W. Dietary vitamin E supplementation affects tissue lipid peroxidation of hybrid tilapia. Oreochromis niloticus×O. aureus. Comp. Biochem. Physiol. B v.134, p.265-270, 2003.

HUANG, S. L.; WENG, Y. M.; HUANG, C. H. Lipid peroxidation in sarcoplasmic reticulum and muscle of tilapia is inhibited by dietary vitamin $E$ supplementation. Journal Food Biochemistry, v.28, p.101-111, 2004.

HUANGA, C.; HUANGB, S. Effect of dietary vitamin E on growth, tissue lipid peroxidation, and liver glutathione level of juvenile hybrid tilapia, Oreochromis niloticusXO. aureus, fed oxidized oil. Aquaculture, v.237, p.381-389, 2004.

HUNTINGFORD, F. A.; ADAMS, C.; BRAITHWAITE, V. A.; KADRI, S.; POTTINGER, T. G.; SANDOE, P.; TURNBULL, J.F. Current issues in fish welfare. Journal of Fish Biology. v.68, p.332-372, 2006. 
JOHNNY, O.; OGUNJI, A; NIMPTSCH, J.; WIEGAND, C.; SCHULZ C. Evaluation of the influence of housefly maggot meal (magmeal) diets on catalase, glutathione S-transferase and glycogen concentration in the liver of Oreochromis niloticus fingerling. Comparative Biochemistry and Physiology, v.147, p.942-947, 2007.

JOHNSTON, W. L.; ATKINSON, J. L.; GLANVILLEA, N. T. A technique using sequential feedings of different coloured foods to determine food intake by individual rainbow trout, Oncorhynchus mykiss: effect of feeding level Aquaculture, v.120, p.123-133, 1994.

JONKER, D., KUPER, C.F., FRAIL, N., ESTRELlA, A., RODRIGUES, OTERO, C. Ninety-day oral toxicity study of lycopene from Blakeslea trispora in rats. Regulatory Toxicology and Pharmacology. V.37, p.396-406, 2003.

JOS, A.; PICHARDO, S.; PRIETO, A. I.; REPETTO, G.; VÁZQUEZ, C. M.; MORENO, I.; et al. Toxic cyanobacterial cells containing microcystins induce oxidative stress in exposed tilapia fish (Oreochromis sp.) under laboratory conditions. Aquat Toxicol. v.72, p.261-71, 2005.

KEYNES, R.G.; GARTHWAITE, J. Nitric oxide and its role in ischaemic brain injury. Current Molecular Medicine. v. 4, p.179-191, 2004.

KOLKOVSKI, S.; CZESNY, S.; YACKEY, C.; MOREAU, R.; CIHLA, F.; MAHAN, D.; DABROWSKI, K. The effect of vitamins $C$ and $E$ in $(n-3)$ highly unsaturated fatty acids-enriched Artemia nauplii on growth, survival, and stress resistance of fresh water walleye Stizostedion vitreum larvae. Aquaculture Nutrition. v.6, p.199206, 2000.

KUBITZA, F. Tilápia e tecnologia e planejamentos na produção comercial, 1 ed. Jundiaí, SP, 2000, 285p.

LARSON, R. A. The antioxidants of higher plants. Phytochemistry. v. 27, p. 969978. 1988.

LAURIDSEN, C.; NIELSEN, J. H.; HENCKEL, P.; SORENSEN, M. T. Antioxidative and oxidative status in muscles of pigs fed rapeseed oil, vitamin $E$, and copper. Journal of Animal Science. v. 77, p. 105-115, 1999. 
LEACH, G.J.; TAYLOR, M.H. The effects of cortisol treatment on carbohydrate and protein metabolism in Fundulus heteroclitus. General and Comparative Endocrinology, v.48, p.76-83, 1982.

LEÃO, J. C.; GERACITANO, L A.; MONSERRAT, J. M.; AMADO, L. L.; YUNES, J. S. Microcystin-induced oxidative stress in Laeonereis acuta (Polychaeta, Nereididae). Mar Environ Res v. 66, p. 92-94, 2008.

LEVY, J., BISIN, E., FELDMAN, B., GIAT, Y., MIINSTER, A., DANILENKO, M., \& SHARONI, Y. Lycopene isa more inhibitor of human cancer cell proliferation than either a-carotene or b-carotene. Nutrition and Cancer, v. 24(3), p.257-266,1995.

LIMA, P. L.; BENASSI, J. C.; PEDROSA, R. C.; DAL MAGRO, J.; OLIVEIRA, T. B.; WILHELM FILHO, D. Time-Course Variations of DNA Damage and Biomarkers of Oxidative Stress in Tilapia (Oreochromis niloticus) Exposed to Effluents From a Swine Industry. Arch. Environ. Contam. Toxicol. v.50, p. 23-30, 2006.

LINE, J.A.; FROST, A.R. Review of opportunities for low stress and selective control of fish. Aquacultural Engineering v.20, p. 211-230, 1999.

LIVINGSTONE, D. R. Oxidative stress in aquatic organisms in relation to pollution and aquaculture. Revue Médecine Vetétérinaire v.154, p. 427-430, 2003.

LIVINGSTONE, D.R. Contaminant reactive oxygen species production and oxidative damage in aquatic organisms, Marine Pollution Bulletin, v.42, p.656-666, 2001

LIVNY, O., KAPLAN, I., REIFEN, R., POLAK-CHARCON, S., MADAR, Z., \& SCHWARTZ, B. Lycopene inhibits proliferation and enhances gap-junctional communication of KB-1 human oral tumor cells. Journal of Nutrition, v.132, p.3754-3759, 2002.

LYGREN, B.; HAMRE, K.; WAAGBO, R. Effect of induced hyperoxia on the antioxidant status of Atlantic salmon Salmo salar L. fed three different levels of dietary vitamin E. Aquaculture Research. v.31, p. 401-407, 2000.

MACKENZIE, D.J.; WONG, S.; RANDALL, D.J.; EGGINTON, S.; TAYLOR, E.W.; FARRELL, A.P. The effects of sustained exercise and hypoxia upon oxygen tensions in the red muscle of rainbow trout. Journal of Experimental Biology. v.207, p.3629-3637, 2004. 
MARTINEZ-ALVAREZ, R. M.; MORALES, A. E.; SANZ, A. Antioxidant defenses in fish: Biotic and abiotic factors. Fish Biology and Fisheries v.15, p.75-88, 2005.

MARTINS, D. A.; AFONSO, L. O. B.; HOSOYA, S.; et al. Effects of moderately oxidized dietary lipid and the role of vitamin $E$ on the stress response in Atlantic halibut (Hippoglossus hippoglossus L.) Aquaculture. v.272:1-4, p.573-580, 2007.

MAZEUD, M.M. e MAZEUD, F. Adrenergic responses to stress in fish. In: Pickering A. D., Stress and Fish. Academic Press, London, p. 49-75, 1981.

MEARNS, K.J. Sensitivity of brown trout (Salmo trutta L.) and Atlantic salmon (Salmo salar L.) fry to amino acids at the start of exogeneous feeding. Aquaculture, v.55, n.1, p.191-200, 1986.

MELO, G.B.; SILVA, R.L.; FAKHOURI, R.; MELO, V.A.; LIMA, S.O. Efeito do omeprazol e do pantoprazol sobre a regeneração hepática após hepatectomia parcial em ratos. Acta Cirúrgica Brasileira. v. 18, p. 542-544, 2003.

MENEZES, H. Própolis: Uma revisão os recentes estudos de suas propriedades farmacológicas. Arquivos do Instituto Biológico. v.72, p. 405-411, 2005

MERCHIE, G.; LAVENS, P.,;SORGELOOS, P. Optimization of dietary vitamin C in fish and crustacean larvae: a review. Aquaculture. v.155, p. 165-181, 1997.

MICHAEL MCCLAIN, R., BAUSCH, I. Summary of safety studies conducted with synthetic lycopene. Regulatury Toxicology and Pharmacology. v.37, n.2, p.274-285, 2003.

MICOZZI, M. S., BEECHER, G. R., TAYLOR, P. R., \& KHACHIK, F. Carotenoid analyses of selected raw and cooked foods associated with a lower risk for cancer. Journal of National Cancer Institute,v.82, p.282-288, 1994.

MONSERRAT, J. M.; KUCHARSKI VENTURA-LIMA, J.; RIBAS FERREIRA, J. L.; ACOSTA, D.; LONGARAY GARCÍA, M.; RAMOS, P. B.; et al. Modulation of antioxidant and detoxification responses mediated by lipoic acid in the fish Corydoras paleatus (Callychthyidae). Comparative Biochemistry and Physiology. v.148C, p. 287-292, 2008. 
MONSERRAT, J. M.; MARTINEZ, P. E.; GERACITANO, L.A.; AMADO, L. L.; MARTINS, C, M. G.; PINHO, G. L. L.; et al. Pollution biomarkers in estuarine animals: critical review and new perspectives. Comparative Biochemistry and Physiology. v.146C, p. 221-34, 2007.

MONTERO, D.; TORT, L.; ROBAINA, L.; VERGARA, J. M.; IZQUIERDO, M. S., Low vitamin $E$ in diet reduces stress resistance of gilthead seabream (Sparus aurata) juveniles. Fish and Shellfish Immunology. v.11, p.473-490, 2001.

MORATA, P.; FAUS, M. J.; PEREZ-PALOMO, M. e SANCHEZ-MEDINA, F. Effect of stress on liver and muscle glycogen phosphorylase in rainbow trout, Salmo gairdneri. Comparative Biochemical and Physiology, v. 78b, p. 421-425, 1982.

MOURENTE, G.; DIAZ-SALVAGO, E.; BELL, J. G.; TOCHER, D. R. Increased activities of hepatic antioxidant defence enzymes in juvenile gilthead sea bream (Sparus aurata L., Osteichthyes, Sparidae) fed dietary oxidised oil: attenuation by dietary vitamin E. Aquaculture. v. 214, p. 343-361, 2002.

NDIWENI, N.; FINCH, J.M. Effects of in vitro supplementation with a -tocopherol and selenium on bovine neutrophil functions: implications for resistance to mastitis. Veterinary Immunology Immunopathology. v. 51, p. 67-78, 1996.

NGUYEN, M. L.; SCHWARTZ,S. J. Lycopene: Chemical and biological properties. Food Technology v. 53, n.2, p.38-43, 1999.

O'CONNOR, K.I.; METCALFE, N.B.; TAYLOR, A.C. Does darkening signal submission in territorial contests between juvenile Atlantic salmon, Salmo salar. Animal Behaviour, v.58, p.1269-1276, 1999.

OKADA, Y.; KANEKO, M.; OKAJIMA, H. Hydroxyl radical scavenging activity of naturally occurring furanfatty acids. Biological and Pharmaceutical Bulletin. v.19, n.12, p.1607-1610, 1996.

OLIVEIRA, M.; PACHECO, M.; SANTOS, M. A. Organ specific antioxidant responses in golden grey mullet (Liza aurata) following a short-term exposure to phenanthrene. Science of the Total Environment. v.39, p.70-8, 2008.

OLIVO, R. Alterações oxidativas em produtos cárneos. In: SHIMOKOMAKI, M.; OLIVO, R.; TERRA, N.N.; FRANCO, B.D.G.M. Atualidades em Ciência e Tecnologia de Carnes. São Paulo: Varela, 2006. p.155-163. 
OMONI, A. O.; ALUKO, R. E. The anticarcinogenic and anti-atherogenic effects of lycopene: a review. Trends in Food Science \& Technology, p.1-7, 2005.

ONIBI, G. E.; SCAIFE, J. R.; FLETCHER, T. C.; HOULIHAN, D. F. 1996. Influence of a-tocopherol acetate in high lipid diets on quality of refrigerated Atlantic salmon (Salmo salar) fillets. Refrigeration and Aquaculture Proceedings of the Conference of IIR Commission C2, 20 - 22 March, Paris, France. International Institute of Refrigeration, Paris, France, p. 145- 152.

OOST, R., BEYER, J., VERMEULEN, N.P.E. Fish bioaccumulation and biomarkers in environmental risk assessment: a review. Environmental Toxicology and Pharmacology, v.13, pp. 57-149, 2003.

ORTUÑO, J.; ESTEBAN, M. A.; MESEGUER, J. The effect of dietary intake of vitamins $C$ and $E$ on the stress response of gilthead seabream (Sparus aurata $L$.). Fish and Shellfish Immunology. v.14, p.145-156, 2003.

ORUC, E.O., SEVGILER, Y., UNER, N., Tissue-specific oxidative stress responses in fish exposed to 2,4-D and azinphosmethyl. Comparative Biochemistry and Physiology. Part C v.137, pp. 43-51,2004.

ORUC, E.O.; UNER, N. Combined effects of 2,4-D and azinphosmethyl on antioxidant enzymes and lipid peroxidation in liver of Oreochromis niloticus. Comparative Biochemistry and Physiology. v.3:C, n.127, p. 291-296, 2000.

OSAWA, C. C.; FELÍCIO, P. E.; GUARALDO GONÇALVES, L. A. Revisão: Teste de Tba aplicado a carnes e derivados: métodos tradicionais, modificados $\mathrm{e}$ alternativos. Quimica Nova, v. 28, n. 4, p. 655-663, 2005

PAETAU, I., KHACHIK, F., BROWN, E. D., BEECHER, G. R., KRAMER, T. R., CHITTAMS, J. Chronic ingestion of lycopene-rich tomato juice or lycopene supplements significantly increases plasma concentrations of lycopene and related tomato carotenoids in humans. American Journal of Clinical Nutrition, v.68, p.1187-1195, 1998.

PALACE, V. P.; WERNER, J. Vitamins $A$ and $E$ in the maternal diet influence egg quality and early life stage development in fish: a review. Scientia Marina v. 70, p. 41-57, 2006. 
PANDEY, S., PARVEZ, S., SAYEED, I., HAQUE, R., BIN-HAFEEZ, B., RAISUDDIN, S. Biomarkers of oxidative stress: a comparative study of river Yamuna fish Wallago attu (BI. \& Schn.). Science of the Total Environment, v.309, pp. 105115,2003

PARIHAR, M.S., JAVERI, T., HEMNANI, T., DUBEY, A.K., PRAKASH, P. Responses of superoxide dismutase, glutathione peroxidase and glutathione antioxidant defenses in gills of the freshwater catfish (Heteropneustes fossilis ) to short-term elevated temperature. Journal of Thermal Biology. v.22, p, 51-56, 1997.

PASCHOAL, J.J.; ZANETTI; M.A.; CUNHA, J.A. Contagem de células somáticas no leite de vacas suplementadas no pré-parto com selênio e vitamina E. Ciência Rural. v.36, p. 1462-1466, 2006.

PEIXOTO, F.; ALVES-FERNANDES, D.; SANTOS, D.; FONTAÍNHASFERNANDES, A. Toxicological eVects of oxyXuorfen on oxidative stress enzymes in tilapia Oreochromis niloticus. Pesticide Biochemistry and Physiology, v.85, p.91-96, 2006.

PENG, S.; CHEN, L.; QIN, J. G.; et al. Effects of dietary vitamin E supplementation on growth performance, lipid peroxidation and tissue fatty acid composition of black sea bream (Acanthopagrus schlegeli) fed oxidized fish oil Aquaculture Nutrition. v.15:3, p. 329-337, 2009.

PETERS, E. M.; ANDERSON, R.; NIEMAN, D. C.; FICKL, H.; JOGESSAR, V. Vitamin $C$ supplementation attenuates the increases in circulating cortisol, adrenaline and anti-inflam-matory polypeptides following ultramarathon running. International Journal Sports Medical, v.22, p.537-543, 2001.

PICKERING, A.D. Introduction: The concept of biological stress. In: Pickering, A.D. (ed) Stress and Fish. Academic Press, London, p.1-9, 1981.

PINHO, G. LL.; ROSA, C. M.; MACIEL, F. E.; BIANCHINI, A.; YUNES, J. S.; PROENÇA, L. A., et al. Antioxidant responses and oxidative stress after microcystin exposure in the hepatopancreas of an estuarine crab species. Ecotoxicology and Environmental Safety. v. 61, p. 353-60, 2005. 
POLITIS, I.; HIDIROGLOU, M.; BATRA, T.R.; GILMORE, J.A.; GOREWIT, R.C.; SCHERF, $H$. Effects of vitamin $E$ on immune function of dairy cows. American Journal Veterinary Research. v. 56, p.179-84, 1995.

PRIETO, A. I.; PICHARDO, S.; JOS, A.; MORENO, I.; CAMEÁN, A. M. Timedependent oxidative stress responses after acute exposure to toxic cyanobacterial cells containing microcystins in tilapia fish (Oreochromis niloticus) under laboratory conditions. Aquatic Toxicology. v.84, p.337-45, 2007.

RAO, A. V., e AGARWAL, S. Role of anti-oxidant lycopene in cancer and heart disease. Journal of the American College of Nutrition, v.19, p.563-569, 2000.

REDDY, P.K.; LEATHERLAND, J.F. Stress Physiology. In: Leatherland, J.F.; Woo, P.T.K. Fish diseases and disorders,v.2. Non-infections disorders. New York: CABI Publishing, p.279- 301, 1998.

RENTfROW, G., LINVILLE, M. L., STAHL, C. A., OlSON, K. C., BERG, E. P. The effects of the antioxidant lipoic acid on beef longissimus bloom time. Journal of Animal Science, v. 82, p. 3034-3037, 2004.

RODRIgUeZ, T.; ALTIERI, A.; CHATENOUD, L.; GALLUS, S.; BOSETTI, C.; NEGRI, E.; FRANCESCHI, S.; LEVI, F.; TALAMINI, R.; LA VECCHIA, C. Risk factors for oral and pharyngeal cancer in young adults. Oral Oncology. v. 40, p. 207-213, 2004.

RODRIGUEZ-AMAYA, D.B. A guide to carotenoid analysis in foods. ILSI Press. Washington. 2001. $64 \mathrm{p}$.

ROSE, J. D. The neurobehavioral nature of fishes and the question of awareness and pain. Reviews in Fisheries Science. v.10, p.1-38, 2002.

ROWE, L. J.; MADDOCK, K. R.; LONERGAN, S. M.; HUFF-LONERGAN, E. Influence of early postmortem protein oxidation on beef quality. American Society of Animal Science. v. 82, p. 785-793, 2004.

RUDNEVA, I. I. Blood antioxidant system of black sea elasmobranch and teleost. Comparative Biochemical Physiology v.122, p.265-271, 1997.

RUFF, N.; FITZGERALD, R. D.; CROSS, T. F.; KERRY, J. P. Fillet shelf-life of Atlantic halibut Hippoglossus hippoglossus L. fed elevated levels of a-tocopheryl acetate. Aquaculture Research, v.33, p.1059- 1071, 2002. 
SARGENT, J. R.; TOCHER, D. R.; BELL, J. G. The lipids. In: Halver JE, Hardy RW (eds) Fish Nutrition, 3rd ed. Academic Press, San Diego, p.182-246, 2002.

SHERIDAN, M. Effects of thyroxine, cortisol, growth hormone and prolactin on lipid metabolism of coho salmon, Oncrhynchus kisutch, during smoltification. General and Comparative Endocrinology, v.64, p.220-238, 1986.

SHI, J., LE MAGUER,M., KAKUDA, Y., LIPTAY, A., \& NIEKAMP, F. Lycopene degradation and isomerization in tomato dehydration. Food Research International, v.32, n.1, p.15-21, 1999.

SIGNORI, J.L.; SIGNORINI, S.L. Atividade física e radicais livres. Aspectos biológicos, químicos, fisiopatológicos e preventivos. Editora Universidade de São Paulo, 1993.

SMITH, C. J.; SHAW, B. J.; HANDY, R. D. Toxicity of single walled carbon nanotubes to rainbow trout, (Oncorhynchus mykiss): respiratory toxicity, organ pathologies, and other physiological effects. Aquatic Toxicology. v. 82, p.94-109, 2007.

SNEDDON, L. U. The evidence for pain in fish: the use of morphine as an analgesic. Applied Animal Behaviour Science. v. 83, p. 153-162, 2003.

STAHL, W., e SIES, H. Lycopene: a biologically important carotenoid for humans? Archives of Biochemistry and Biophysics, v.336, p.1-9, 1996.

STE'PHAN, G.; GUILLAUME, J.; LAMOUR, F. Lipid peroxidation in turbot (Scophthalmus maximus) tissue: effect of dietary vitamin $E$ and dietary $n-6$ or $n-3$ polyunsaturated fatty acid. Aquaculture, v.130, p.251-268, 1995.

SUMMO, C.; CAPONIO, F.; PASQUALONE, A. Effect of vacuum-packaging storage on the quality level of ripened sausages. Meat Science, v.74, p.249-254, 2006.

TAPIERO, H., TOWNSEND, D.M., TEW, K.D. The role of carotenoids in the prevention of human pathologies. Biomed Pharmacother. v.58, p.100-110, 2004.

THOMPSON, K. A., MARSHALL, M. R., SIMS, C. A., WEI, C. I., SARGENT, S. A., \& SCOTT, J. W. Cultivar, maturity, and heat treatment on lycopene content in tomatoes. Journal of Food Science: Food Chemistry and Toxicology, v.65, n.5, p.791-795, 2000. 
TOCHER, D. R.; MOURENTE, G.; VAN DER EEKEN, A.; EVJEMO, J. O.; DIAZ, E.; BELL. J. G.; GEURDEN, I.; LAVENS, P.; OLSEN, Y. Effects of dietary vitamin E on antioxidant defence mechanisms of juvenile turbot (Scophthalmus maximus L.), halibut (Hippoglossus hippoglossus L.) and sea bream (Sparus aurata L.). Aquacultutre Nutrition. v.8, p. 195-207,2002.

TRENZADO, C. E.; LA HIGUERA, M.; MORALES, A. E. Influence of dietary vitamins $\mathrm{E}$ and $\mathrm{C}$ and HUFA on rainbow trout (Oncorhynchus mykiss) performance under crowding conditions. Aquaculture, v.263, p.249-258, 2007.

TRENZADO, C. E.; MORALES, A. E.; PALMA, J. M.; DE LA HIGUERA, M. Blood antioxidant defenses and hematological adjustments in crowded /uncrowded rainbow trout (Oncorhynchus mykiss) fed on diets with different levels of antioxidant vitamins and HUFA Comparative Biochemistry and Physiology, v.149 C, p. 440-447, 2009.

TRUSHENSKI, J. T.; KOHLER, C. C. Influence of stress and dietary natural-source vitamin $\mathrm{E}$ on nonspecific immunocompetence, tissue tocopherol composition, and postslaughter fillet oxidative stability in sunshine bass North American Journal Of Aquaculture. v.69:4, p. 330-339, 2007.

URBINATI, E. e CARNEIRO, P. C. Práticas de manejo e estresse dos peixes em piscicultura. Tópicos Especiais em Piscicultura de Água Doce Tropical Intensiva. São Paulo: TecArt, p.533, 2004.

URSO, M. L.; CLARKSON, P. M. Oxidative stress, exercise, and antioxidant supplementation. Toxicology v.189, p.41-54, 2003.

URSO, M.L.; CLARKSON, P.M. Oxidative stress, exercise, and antioxidant supplementation. Toxicology, v. 189, p. 41-54, 2003.

VALLE, C. R. Estudo da influência da suplementação de vitamina $E$ nas atividades funcionais dos neutrófilos do leite de bovinos. 2005 . 82 f. Tese (doutorado) - Faculdade de Zootecnia e Engenharia de Alimentos, Universidade de São Paulo, Pirassununga, 2005. 
VEGA-LÓPEZ, A.; GALAR-MARTÍNEZ, M.; JIMÉNEZ-OROZCO, F. A.; GARCÍALATORRE, E.; DOMÍNGUEZ-LÓPEZ, M. L. Gender related differences in the oxidative stress response to PCB exposure in an endangered goodeid fish (Girardinichthys viviparus) Comparative Biochemistry and Physiology, Part A v.146, p.672-678, 2007.

VEISIER, I.; FORKMAN, B. The nature of animal welfare science. Annual Review of Biomedical Sciences, v.10, p.15-26, 2008.

VELMURUGAN, B., SANTHIYA, S.T., NAGINI, S., Protective effect of S-allylcysteine and lycopene in combination against $N$-methyl- $N_{-}$-nitro- $N$-nitrosoguanidineinduced genotoxicity. Polish Journal of Pharmacology. V.56, p.241-245, 2004.

VIJAYAN, M.M.; LEATHERLAND, J.F. Effect of stocking density on the growth and stress response in brook charr, Salvelinus fontinalis. Aqualculture, v.75, p.159$170,1989$.

VIJAYAN, M.M.; PEREIRA, M.C.; MOON, T.W. Hormonal stimulation of hepatocyte metabolism in rainbow trout following an acute handling stress. Comparative Biochemistry and Physiology, v.108, p.321-329, 1994 (a).

VIJAYAN, M.M.; REDDY, P.K.; LEATHERLAND, J.F.; MOON, T.W. The effects of cortisol on hepatocyte metabolism in rainbow trout. A study using the steroid analog RU486. General and Comparative Endocrinology, v.96, p.75-84, 1994(b).

VINAGRE, T. M.; ALCIATI, J. C.; REGOLI, F.; BOCCHETTI, R.; YUNES, J. S.; BIANCHINI, A.; et al. Effect of hepatotoxins (microcystin) on ion-regulation and antioxidant system in gills of Chasmagnathus granulatus (Decapoda, Grapsidae). Comparative Biochemistry and Physiology. v.135C, p. 67-75, 2003.

VOLPATO G. L.; BARRETO, R. E. Environmental blue light prevents stress in the fish Nile tilapia. Brazilian Journal of Medical and Biological Research v.34, p. 1041-1045, 2001.

VOLPATO, G. L.; GIAQUINTO, P. C.; CASTILHO, M. F.; BARRETO, R. E.; GONÇALVES-DE-FREITAS, E. Animal Welfare: from CONCEPTS to reality Oecologia Brasileira. v.13:1, p. 05-15, 2009. 
VOLPATO, G. L.; GONÇALVES-DE-FREITAS, E.; FERNANDES-DE-CASTILHO, M. Insights into the concept of fish welfare. Diseases of Aquatic Organisms, vol. 75, p.165-171, 2007.

VOLPATO, G. L.; LUCHIARI, A. C.; DUARTE, C. R. A.; BARRETO, R. E.; RAMANZINI, G. C. Eye color as an indicator of social rank in the fish Nile tilapia. Brazilian Journal of Medical and Biological Research, v.36, p.1659-1663, 2003.

VOLPATO, G.L.; FRIOLI, P.M.A.; CARRIERI, M.P.; FERNANDES, M.O.; SARTORI,D.R.S.; BELICIO,H.C. Comportamento de dominância e crescimento em peixes. In: COSTA, M. J. R. P.;NASCIMENTO JÚNIOR, A.F., eds. Anais de Etologia, Jaboticabal, v.5, p.169-194. 1987.

WEISBURGER, J. H. Evaluation of the evidence on the role of tomato products in disease prevention. Proceedings of the Society for experimental biolog and medecie v.218, p.140-143, 1998.

WENDELAAR BONGA, S. E. The stress response in fish. Physiological Reviews v. 77, pp. 591-625, 1997

WHILHELM-FILHO, D. Fish antioxidant defences-a comparative approach, Brazilian Journal Medical Biological Research. v. 29, p.1735-1742, 1996.

WINSTON, G. W.; DI GIULIO, R. T. Prooxidant and antioxidant mechanisms in aquatic organism. Aquatic Toxicology, v.19, p.137-161, 1991

YEATES, J. W.; MAIN, D. C. J. Assessment of positive welfare: a review. The Veterinary Journal, v.175, p. 293-300, 2008. 